\title{
BİLSEM Tanılama Sürecinde Kullanılan Zeka Testlerinin Psikolojik Danışmanların ve BİLSEM Öğretmenlerinin Görüşlerine Göre Değerlendirilmesi*
}

\author{
AHMET KURNAZ \\ SEMRA (GÖKDEMIR] EKICI
}

Özet

Özel yetenekli çocukların eğitiminde ilk adım onların tespit edilerek uygun bir şekilde tanılanmasıdır. Üstün zekâlı/yetenekli çocukların tanılanması, onlara uygun eğitim olanaklarının sunulması açısından büyük önem taşımaktadır. Özellikle bir çocuktaki mevcut yetenekler ne kadar erken fark edilirse, o ölçüde sahip olduğu kapasitenin körelmesine etki edecek faktörlerden uzak kalabilir ve yeteneklerinin geliştirilmesi için uygun ortam sağlanabilir.

Ülkelerin gizli cevherleri olan özel yetenekli çocukları eğitebilmek için ilk önce onların tespit edilerek uygun bir şekilde tanılanması gerekmektedir. Ülkemizde üzerinde mutabık kalınmış bir tanılama yöntemi yoktur. Mevcut seçme

* Semra GÖKDEMİR'in 2017 yılında yaptığ1 “Ülkemizde özel yetenekli öğrencilerin tanılama sürecinin öğretmen, veli ve öğrenci görüşlerine göre değerlendirilmesi” başlıklı yüksek lisans tezinden üretilmiştir.

- ARASTIRMA MAKALESI-

AHMET KURNAZ, akurnaz@erbakan.edu.tr Necmettin Erbakan Üniversitesi ORCID: https://orcid.org/ORCID: 0000-0003-1134-8689

SEMRA (GÖKDEMIR] EKICi semraekici1981@hotmail.com Fethiye Cumhuriyet io. ORCID: https://orcid.org/ORCID: 0000-0001-5043-4729

Gelis Tarihi 26.08.2020 • Kabul Tarihi 16.11.2020 doi: https://doi.org/10.47646/CMD.2020.177 
etkinlikleri eğitimci, aile ve öğrenci görüşlerinden bağımsız yürütülmektedir. Bu araştırmanın amacı, ülkemizde özel yetenekli öğrencilerin tanılanması sürecinde kullanılan tanılama araçlarının olumlu-olumsuz yönlerini belirleyerek, tanılama sürecinin netleştirilmesine yardımcı olmak ve sürecin daha sağlıklı yürümesine 1şık tutabilecek tespitler yapabilmektir.

$\mathrm{Bu}$ araştırmada, nitel araştırma yöntemlerinden durum çalışması deseni kullanılmıştır. Araştırmanın katılımcılarını 18 BíLSEM öğretmeni ve 15 Psikolojik Danışman oluşturmaktadır. Veri toplama aracı olarak araştırmacılar tarafından sabit form görüşme anketi oluşturulmuştur. Verilerin analizi aşamasında, betimsel analiz ve içerik analizi yöntemi birlikte kullanılmıştır.

Araştırma sonunda Psikolojik Danışmanların düşüncelerine göre okul öncesi çocukların tanılanmasında zekâ testi kullanılmadığı ve uygulamaların ilden ile farklılık gösterdiği; grup tarama uygulamasının merkezi sistemle aynı anda yapılmasının daha nesnel ve adil olduğu; WISC-R testinin uygulamasının zor olduğu ve uzun zaman aldığı, ulaşılabilirliği arttığı bu yüzden güvenirliliğini yitirdiği için revizyona ihtiyacı olduğu; BİLSEM tanılama sürecinde WISC-R testi yerine WNV Testinin uygulanıyor olmasının olumlu bulunduğu; WNV testinin sözel bölümünün eksik oluşunun eleştiri konusu olduğu; WNV testinin öğrencilere uygulanma sürecinin sağlıklı işlediği; WNV yetenek testi üstün zekâyı ayırt etmede oldukça iyi bulunmakla birlikte sözel bölümünün olmaması yönüyle eksik bulunduğu sonuçlarına ulaşılmıştır. BİLSEM öğretmenlerinin görüşlerine göre BİLSEM kabul yaşı okul öncesi döneme alınması gerektiği, önceki yıllarda TKT ile seçilenler ile son yıllarda grup tarama uygulamaları ile seçilenler arasında zihinsel performans ve uyum süreci açısından fark olmadığı, BILLSEM tanılama sürecinde öğrencilerin seçilme yöntemlerinde sıkıntılar yaşandığı, BİLSEM öğretmenleri WNV testi hakkında bilgilendirilmemiş olduğunu, WISC-R testi üstün zekâyı ayırt ediciliği yüksek bir test olmakla birlikte güncel bir testin uygulanmasının olumlu olduğu sonuçlarına ulaşılmıştır.

Anahtar Kelimeler: Özel yetenekli/üstün zekâlı, tanılama süreci, zeka testleri, psikolojik danışman

\section{Abstract}

The first step in the education of gifted students is to identify them. Identifying gifted students is of great importance in terms of providing them suitable education. The earlier the talents of a child are realized, the more he can be kept away from the factors that dampen his capacity and the more chances he finds to improve his talents.

Çocuk ve Medeniyet 2020/2
In order to educate the gifted students, hidden treasures of their countries, they must be identified. In our country, there is no identification method commonly agreed on. The present selection activities are carried out without receiving 
the opinions of educators, families and students. This study aims to clarify the identification process and tools of gifted students by defining positive and negative sides of identification tools and it also aims to determine the factors which help to carry out the process more healthily.

This study was conducted through case study, one of the qualitative methods. 18 Art and Science Center (ASC) teachers and 15 psychological counselors participated in the study. A fixed interview form developed by researchers was used as a data collection tool. Data was analyzed through descriptive and content analysis.

According to views of psychological counselors it was found out that (i) no intelligence test is used in the identification process of pre-school children and implementations differ from city to city, (ii) group identifications must be done at the same time and centrically to ensure objectiveness and justice, (iii) WISC-R test is hard to implement and takes a lot of time, (iv) since it becomes easier to access the test and its reliability decreased, it needs revision (v) they have positive views for the implementation of WNV instead of WISC-R, (vi) they criticize the lack of quality of the verbal section of WNV, (vii) the implementation process of WNV undergoes healthily, (viii) despite its lack of a verbal section, WNV is found quite sufficient in determining the giftedness. According to the views of ASC teachers it was found out that (i) the acceptance age for ASCs must be started as early as pre-school period, (ii) there is no difference between the students who are formerly selected by basic capabilities test and who are selected by group identification process in terms of mental performance and orientation process, (iii) there are some problems in the identification methods used by ASCs to select students, (iv) ASC teachers are not informed about WNV test, (v) though WISC-R is highly sufficient in identifying giftedness, it is preferable to implement a more up-to-date test.

Keywords: Gifted, identification process, intelligence tests, psychological counselors

\section{Giriş}

Günümüzde birey ve toplumları yakından ilgilendiren değişim ve gelişimler baş döndürücü bir hızla meydana gelmektedir. Değişim sürecinde, her toplum rekabet gücünü artırmak için inovasyon çalışmalarına daha fazla bütçe ayırmak zorunda kalmaktadır. Küresel anlamda rekabet edebilmek için ekonomik gücün yanında insan gücünün de önemi büyüktür. İnsan gücünün niteliğinin artırılması, toplumdaki üstün zekalı ve yetenekli bireylerin keşfedilerek, toplumun ihtiyaç ve beklentileri doğrultusunda yetiştirilmesi ile mümkündür. Üstün zekalı ve yetenekli bireylerin sahip 
oldukları potansiyelin farkına varmalarını sağlamak, yaratıcılıklarını ortaya çıkarmalarını teşvik etmek ve topluma faydalı olabilecek görevlerde yer almalarını sağlamak son derece önemlidir (Davaslıgil, 2004).

Tarihi süreç incelendiğinde üstün zekâ ve üstün yetenek için çok çeşitli tanımlar yapıldığı dikkat çekmektedir. Evrensel ve ortak bir tanım üzerinde uzlaşıya varılamamıştır. Ülkemizde kabul gören tanıma göre “Özel yetenekli Çocuk/Öğrenci: Zekâ, yaratıcılık, sanat, liderlik kapasitesi veya özel akademik alanlarda yaşıtlarına göre yüksek düzeyde performans gösterdiği uzmanlar tarafından belirlenen çocuk/öğrencileri” ifade eder (Milli Eğitim Bakanlığı [MEB], 2007). Amerika Birleşik Devletleri Millî Eğitim Bakanlığı'nın kabul etmiş olduğu tanımda üstün zekâlı çocuk yerine üstün yetenekli çocuk kavramı kullanılmış olup; "akranlarına göre olağanüstü düzeyde başarı veya başarı potansiyeli gösteren çocuk" üstün yetenekli olarak kabul edilmiştir. Bu çocukların; zihinsel, yaratıcılık, sanatsal alanlarda yüksek performans kapasitesi gösterdiklerinin, sıra dışı liderlik kapasitesine sahip olduklarının veya akademik alanlarda olağanüstü başarı gösterdiklerinin altı çizilmiştir (Sak, 2014). İngilizcede yeteneğin alanına bağlı olarak kullanılan iki ayrı terim vardır: "Gifted" ve "talented". İlki tanrının bir armağan bahşettiği kişi anlamına gelmektedir. İkincisi ise bir marifeti, hüneri bulunan kişi demektir. Özellikle İngiltere'de bunların ikisini de içeren "ability" sözcüğü bilim ve eğitim çevrelerinde daha çok rağbet görmektedir (Akarsu, 2004). Bununla birlikte sadece yüksek zekâ bölümü gibi tek ölçüte dayalı tanımlar zamanla yerini çoklu ölçüte dayalı tanımlara bırakmıştır (Davaslıgil, 2016).

Ülkemizde özel yeteneklilerin eğitimlerine yönelik ilk uygulamalar 1920'li yıllara kadar dayansa da henüz özel yeteneklilerin eğitimlerine ilişkin standartların ve değerlendirme kriterlerinin oluşmadığı görülmektedir. Alanda kabul görmesi bakımından Amerika Birleşik Devletleri Ulusal Üstün Zekâlı Çocuklar Derneği (NAGC) standartları fikir vermesi bakımından iyi bir örnek olabilir. NAGC'nin tanımına göre tanılama, bütün alanlar için öğrencilerdeki gelişim ve program değerlendirmesi hakkında bilgi veren bir uygulamadır. NAGC program standartları arasında, tanılamayla doğrudan ilişkili olarak tanılamanın standartlar öğrencilerin kendilerine özgü özellikleri ve davranışları yansıtabilecekleri kapsamlı değerlendirmelere katılım haklarının korunması, öğrenciler potansiyellerini farklı tanılama araçları ile daha iyi ortaya koyabilmesi ve tanılanan öğrenciler arasında egemen kültürden gelen öğrencilerin yanı sıra farklı kültür ve sosyoekonomik çevreye sahip öğrencilerin temsili de bulunması olarak belirtilmiştir (NAGC, 2013). 
Özel yetenekli öğrencilerin eğitiminde tanılama uygulamalarının genel amacı öğrenciler hakkında eğitsel kararlar almaktır. Özel yetenek tanımları tanılama uygulamaları için kuramsal bir dayanak oluşturmakla beraber bu tanımların hangi amaçla yapıldığı da önemlidir. Bu bağlamda tanılama amaçları ve tanılama arasındaki uyum tanılamanın geçerliğinin bir göstergesi olarak değerlendirilebilir. Özel yeteneklilerin eğitiminde tanılama, herhangi bir programa uygun öğrencilerin belirlenmesi süreci olarak değerlendirilebilir. Sak (2013), tanılamanın bireysel ve toplumsal olmak üzere iki amaçla yapıldığını belirtmiştir. Bu fikre göre tanılama öğrenciye fayda sağlamak ve dolaylı olarak topluma fayda sağlamak amacıyla yürütülmelidir. Ancak tanılamanın kendi başına bir fayda sağlamayacağı açıktır (Ayas, 2019).

Üstün zekalı ve yetenekli öğrencilerin tanılamasında kullanılan yöntemleri bireye dayalı tanılama ve programa dayalı tanılama olmak üzere iki başlık altında toplamak mümkündür (Ataman, Dağlığlu ve Şahin, 2014). Tanılama, belirli özellikleri taşıyan ya da belirli bir sınıfa giren kişileri belirleme süreci olarak tanımlanabilir. Özel yetenekli öğrencileri tanılama; zekâ, yaratıcılık ve başarı gibi bireysel özelliklere ilişkin bilgilerin toplandığı ve bu bilgiler doğrultusunda öğrencilerin zihinsel kapasiteleri veya potansiyelleri hakkında kararların alındığı bir süreci kapsar. Bu süreçte öğrenci ile ilgili olarak toplanan bilgilerin detaylı, doğru ve güvenilir olması; bilgi toplama araçlarının çeşitliliği ve farklı disiplinlerden uzmanların tanılama sürecine katkıda bulunmaları tanılamanın kalitesini arttırır. Özel yetenekli öğrencilerin tanılanmaları ve özel eğitim almaları uzmanlar ve eğitimciler arasında yaygın olarak destek bulan ancak bir o kadar da görüş ayrılığı ve tartışma yaratan bir sorundur. Örneğin tanılama ile ilgili olarak aşağıdaki '4N' soruları uzmanlar arasında her zaman tartışmalı fikirlerin ortaya çıkmasına neden olmuştur.

Özel yeteneklilerin eğitiminde çok farklı tanılama uygulamaları geliştirilmiştir. Tanılama uygulamalarındaki bu çeşitlilik tanılamaya ilişkin tartışmalara hem kaynaklık etmekte hem de bu tartışmaların bir sonucu olarak karşımıza çıkmaktadır. Heller (2004) tanılama uygulamalarında "Ne tanılanmalıdır? Özel yeteneğin göstergeleri nelerdir? Neden tanılama yapılmalıdır? Tanılama hangi amaçla yapılmalıdır? Nasıl tanılama yapılmalıdır? Tanılamada ne tür bilgiler, araçlar ve yöntemler kullanılmalıdır? Ne zaman tanılama yapılmalıdır? Tanılama eğitim sürecinin hangi aşamasında yapılmalıdır? Bir defada mı yoksa devam eden bir süreç 2020/2 şeklinde mi olmalıdır?” sorularının kuramsal ve yöntemsel seçimlerin çerçevesini oluşturması bakımından önemli olduğunu belirtir (Ayas, 2019).

BİLSEM Tanılama Sürecinde Kullanılan Zeka Testlerinin Psikolojik Danışmanların ve BİLSEM Öğretmenlerinin Görüşlerine Göre Değerlendirilmesi 
Tanılama sürecinde kriter ya da amaç ne olursa olsun bireyin yüksek yararının göz önünde bulundurulması, tanılamada kullanılan yöntemlerin bilimsel, objektif, kapsamlı ve tarafsız olması, tanılamanın erken yaşlarda yapılması (Eker ve Sarı, 2016) tüm bireylere fırsat eşitliği sunulması ve sistematik olarak her sınıf ve yaş düzeyinde tanılama yapılarak sürekliliğe önem verilmesi, tanılama sürecinde kullanılan ölçme değerlendirme araçlarının bireyin özelliklerinin yanı sıra eğitim programlarının amaç ve içerikleri ile uyumlu olması ve tanılama sonunda verilecek yönlendirme kararının disiplinler arası çalışan bir ekip tarafından alınması gibi temel ilkelerin göz önünde bulundurulması gerekir (MEB, 2010). Tanılama ile ilgili temel hassasiyetler dikkate alındığında ve tanılamanın gerekliliğine karar verildiğinde farklı tanılama yöntemleri kullanılabilir. Bu yöntemler aşağıda yer almaktadir.

Tanılama süreci nitel ya da nicel araştırma yöntemlerine dayanabilir. Callahan (2005) araştırmalarda bu iki yöntemin birlikte, ardışık kullanıldığı çoklu değerlendirme yöntemlerinin daha başarılı bulunduğunu belirtmiştir. Bu bağlamda birçok programda standardize edilmiş bireysel testlerin kullanımı gibi nicel tanılama yöntemleri ile gözlem ve görüşmeye dayalı nitel tanılama yöntemlerinin birlikte kullanıldığını görmekteyiz. Sak (2014) üstün yeteneklilerin tanılanmasında kullanılan yöntemleri Norm tabanlı Örneklem tabanlı ve Ölçüt tabanlı tanılama olarak sınıflandırır. Norm grubu ile standartlaştırılmış teste tabi tutulan bireyin performansı karşılaştırılarak yapılan tanılama yöntemidir. Bu tür tanılama yönteminde norm ve standardizasyon çalışmaları yapılmış testler kullanılmaktadır. Örneklem tabanlı tanılama herhangi bir norm grubu ile karşılaştırma yapılmaksızın örneklem içinde yer alan bireylerin grup içindeki yerini ve durumunu gösteren tanılama türüdür. Ölçüt tabanlı tanılama ölçme aracında bir eşik değer belirlenerek yapılan tanılamadır. Bu yöntemde tanılama ölçeğinde temel alınan ölçüt değerin üstü başarılı kabul edilir.

Tanılamada yöntemlerin yanı sıra iki tür de yaklaşımdan bahsetmek mümkündür. Bu yaklaşımlar bireye dayalı tanılama ve programa göre tanılama olmak üzere iki başlıkta ele alınabilir. Bireye dayalı tanılama yaklaşımı ile önce öğrencilerin zihinsel kapasitelerinin düzeyleri psikometrik araçlar ile belirlenir. Daha sonra öğrencilerin zihinsel ve akademik özelliklerine göre eğitim programları geliştirilmeli ya da var olan eğitim programları öğrencilerin özelliklerine göre uyarlanmalıdır. Bireye dayalı tanılama sürecinde norm tabanlı, örneklem tabanlı veya ölçüt tabanlı tanılama yöntemlerinden herhangi biri kullanılabilir. Bu tip tanılama sürecini benimseyen kişiler ölçümlerinde daha çok genel zekâyı ölçen araçları kullanma eğilimi gösterirler (Sak, 2014). 
Ülkemizde bireysel düzeyde yapılan tanılama biçimine Bilim ve Sanat Merkezi (BİLSEM) öğrenci seçimleri örnek gösterilebilir. Ülkemizin mevcut ekonomik, sosyal, kültürel ve eğitim şartları dikkate alınarak daha fazla özel yetenekli çocuğa en uygun modelle ulaşılabilmesi için farklı ülkelerde uygulanan modeller incelenmiştir. Bu modellerin uygulanabilirlikleri tartışılmış ve ülkemizin şartlarına uygun olarak başlangıçta "ek ders uygulama okulu" daha sonra da BILLSEM olarak adlandırılan bir proje başlatılmış ve BİLSEM'lerin kuruluşu gündeme gelmiştir. 1996 yılında Millı̂ Eğitim Bakanlığı Özel Eğitim Rehberlik ve Danışma Hizmetleri Genel Müdürlüğü’nün “illköğretim Çağı Öğrencilerinin Özel Yeteneklerini Geliştirme" projesi ile başlayan çalışmalar sürmüş ve Millî Eğitim Bakanlığı Özel Eğitim Rehberlik ve Danışma Hizmetleri Genel Müdürlüğü bünyesinde BİLSEM'ler oluşturulmuştur. Bugün sayıları itibariyle 80 ilde 106'ya ulaşmıştır (MEB, 2017). BİLSEM, okul öncesi, ilköğretim ve ortaöğretim çağındaki Özel yetenekli çocuk/öğrencilerin bireysel yeteneklerinin farkında olmalarını ve kapasitelerini geliştirerek en üst düzeyde kullanmalarını sağlamak üzere açılan özel eğitim kurumlarıdır (MEB, 2007). BİLSEM modelinde özel yetenekli çocuklar, temel eğitime dayalı bilgileri yaşıtlarıyla birlikte devam ettikleri okullarından almakta olup, BİLSEM'de ise özel yetenekli oldukları bilim ve sanat alanında, diğer okullardan gelen benzer arkadaşları ve alan öğretmenleri ile çalışma fırsatı bulmaktadırlar. Bu anlamda bu modelin en önemli avantajlarından biri özel yetenekli çocukların kendi okullarında akranlarından, arkadaşlarından soyutlanmadan ileride toplum adına yapacakları çalışmalarda, toplum bireylerini zihinsel, sosyal, kültürel ve duygusal açıdan tanıyabilme olanağına sahiptirler. BILLSEM'e öğrenci seçimi üç aşamada gerçekleşmektedir. Öğrenci seçiminin ilk aşamasını sınıf öğretmenlerinin doldurduğu "ìlköğretim Çağı Öğretmen Gözlem Formu” oluşturmaktadır. Gözlem formlarına göre özel yetenekli tanılaması için önerilen öğrenciler, tanılama sürecinin ikinci basamağı olan Temel Kabiliyetler Testine (TKT 7-11), burada başarı gösterenler üçüncü basamağı olan WISC-R testine girmekte (Sıcak, 2014) idiler. 2015 yılından beri ise öğretmenlerin gözlem formlarını elektronik başvuru sistemi üzerinden doldurmasının ardından tabletler aracılığı ile uygulanan grup testi ve grup tanılamasından belirlenen puanları alan öğrenciler de bireysel zeka testine tabi tutulmaktadır.

Programa dayalı tanılama yaklaşımı ile önce eğitim programları geliştirilir, daha sonra bu programların özelliklerine uygun yeteneği olan öğrenciler tanılanır. Programa dayalı tanılamada yukarıda ele alınan yöntemlerden her üçü de kullanılabilir. Bu tür tanılama sürecinde daha çok alana özgü yetenekleri ölçen psikometrik araçlar kullanılmalıdır. Eğitim programının

BİLSEM Tanılama Sürecinde Kullanılan Zeka Testlerinin Psikolojik Danışmanların ve BİLSEM Öğretmenlerinin Görüşlerine Göre Değerlendirilmesi 
özelliklerine uygun yeteneği olan özel yetenekli öğrencilerin tanılanması, programın içeriği ile öğrencilerin yetenek profilleri arasında iyi bir uyum yaratabilir. Bu uyum hem programın başarı şansını hem de öğrencilerin programdan en üst düzeyde yararlanma olasılıklarını artırır. Diğer yandan, programa dayalı tanılama yaklaşımının daha ekonomik olduğunu söyleyebiliriz. Çünkü bu yaklaşım ile hedef kitle doğrudan tanılanabilmekte ve tanılamadan sonra ek ölçümlere gerek kalmamaktadır. Son yıllarda Türkiye'de eğitim programlarında yapılan çoğu yetenek eğilimli değişiklikler de programa dayalı tanılama yaklaşımının kullanımını destekler niteliktedir (Sak, 2014).

Çeşitli ülkelerde üstün yeteneği tanılama ile ilgili olarak farklı politika, model ve stratejiler bulunmaktadır. Bazı tanılama süreçleri sadece zekâ puanı üzerinde dururken, bazıları çok boyutlu değerlendirmenin avantajlarından ve öneminden bahsetmektedir. Ancak ideal bir tanılama sisteminden bahsetmek de mümkün değildir. Bunun çok çeşitli nedenleri bulunmaktadır. Örneğin öğrenciler, birbirlerinden farklı düzeylerde farklı yeteneklere sahiptir (Clark, 1997). Standardize zekâ testlerinin, akademik ve genel yetenek haricindeki yetenek alanlarını ölçme bakımından sinırlılıkları vardır (Sternberg, Jarvin ve Grigorenko, 2011). Araştırmalarda yetenek alanlarındaki çeşitlilik, yeteneğin kendini gösterebileceği ve geliştirilebileceği ortamlara erişememesi, yetenek belirleme ölçeklerinin sınırlılıkları, ekonomik ve kültürel dezavantaj gibi etmenlerin üstün yetenekli öğrencilerin fark edilmesini zorlaştırdığı görülmüştür (Clark, 1997; Kuzgun, 2004; Sternberg ve diğerleri, 2011; Tomlinson ve diğerleri, 2002).

Bir öğrencinin özel yetenekli olarak tanılaması, özel yetenekli bireyin, ailenin ve yakın çevrenin tutumlarında değişikliklere neden olabilmektedir. Özel yetenekli olarak tanılanan bireyin kendisinden ve aile bireylerinden beklentileri farklılaşabilmektedir. Bu farklılaşmaya paralel olarak özel yetenekli bireyler de pozitif ve negatif tepki verebilmektedir. Bununla birlikte özel yetenekli olarak seçilemeyen bireylerin de kendilik beklentileri ve kendilik algılarında bazı olumsuz gelişmeler söz konusu olabilmektedir. Bu anlamda tanılama, bireyin yaşantısını önemli ölçüde etkileyen, kritik, dikkatli ve ayrıntılı olarak ele alınması gereken bir süreç olarak karşımıza çıkmaktadır (Türkiye Büyük Millet Meclisi [TBMM], 2012).

Özel yetenekli öğrencilerin tanılama sürecinde birden fazla kaynaktan bilgi toplanması son derece önemlidir. Örneğin, tanımama sürecinde zekâ testlerinin isabetlilik oranı \%60, öğretmenlerin isabetlilik oranı $\% 45$, yaratıcılık testlerinin isabetlilik oranı \%10'unu, akademik başarı testlerinin isabetlilik oranı \%60'tır. Zekâ testlerinin ve başarı testlerinin birlikte 
kullanıldığı tanılama uygulamalarında ise doğru tanılama oranı \%90'a kadar çıkabilmektedir (Sak, 2014). Bunun yanı sıra kullanılmakta olan ölçeklerin, zekânın değişik niteliklerinden çok, genel zihin gücünü ölçtügüune ilişkin eleştiriler söz konusudur. Sahip olduğu zeka ve/veya yetenek düzeyi yaşıtlarının çok üstünde olan çocukları tanılamak, düzeylerinin açıkça fark edilebilir olmasından dolayı çok kolaydır. Ancak, ortalamanın biraz üstünde yetenek gösteren çocukların yaşıtlarına göre farklılığı bu kadar belirgin olmadığından, durumlarını belirlemek için bazı saptamaların yapılması gerekebilir (Levent, 2011).

Buna karşın, ülkemizde özel yetenekli çocukların belirlenmesi genel itibariyle, öğretmenleri tarafından aday gösterilen öğrencilerin bir takım grup ve bireysel testlerinden geçirilmesi sonucunda gerçekleşmektedir. Bu noktada aday gösterme sürecinde öğretmen faktörü çok önemlidir. Öğretmenler öğrencinin sınıf içi genel davranışlarına ve içinde bulunduğu sosyokültürel düzeye göre yanlı (Ataman ve diğerleri, 2014) davranabilirler. Yani, popüler kültür içerisinde yer alan öğrencileri, öncelikle erkekleri ve yüksek sosyoekonomik ve kültürel düzey içerisinde yer alan bireyleri diğer akranlarına göre daha fazla aday gösterme eğilimi içerisine girmektedirler. Bunun yanı sıra öğretmenlerin deneyimleri aday gösterme sürecinde rol oynamaktadır. Deneyimsiz öğretmenler deneyimli öğretmenlere göre daha az aday gösterme eğilimindedirler. Ayrıca, sosyal ve devinişsel alanda ileri olanların aday gösterilmede bilişsel alan kadar göz önünde bulundurulmadığı gözlemlenmektedir (Ataman ve diğerleri, 2014). Bazı öğretmen ve idareciler hala özel yetenekli öğrenciye verilecek ekstra zamanı antidemokratik olarak algılamaktadır. Aynı şekilde, onları özel sınıflara yerleştirip özel eğitim vermek de antidemokratiktir. Bazıları da herhangi bir öğrenciye 'parlak zekâlı' tanımı yapılmasını sakıncalı bulur. Öyle tanılama yapılıp da özel zaman verilince aynı düzeydeki diğer zeki çocukların ihmal edileceklerinden çekinirler (Ersevim, 2001).

MEB (2010) İç Denetim Birimi Başkanlığı Bilim ve Sanat Merkezleri Tanılama Süreci (Özel yetenekli Bireylerin Eğitimi) İç Denetim Raporu anket uygulamasında, ankete katılanların büyük bir çoğunluğu, okullardaki öğretmenlerin, özel yetenekli öğrencilerin ayırt edici özellikleri konusunda yeterince bilgi sahibi olmadığı görüşünde birleşmektedir. Böyle bir riskin bulunması, aday gösterilebilecek durumda olan öğrencilerin aday gösterilmeyerek mağdur olmasına neden olabilecektir. Ayrıca okullarda yürütülen öğretim faaliyetlerinin zihinsel performansı ortaya çıkarmaktan çok bilgileri ezberleme ve akılda tutmaya dayalı olması özel yetenekli öğrencilerin performanslarını sergileme imkânı bulamamasına neden olmaktadir.

BİLSEM Tanılama Sürecinde Kullanılan Zeka Testlerinin Psikolojik Danışmanların ve BİLSEM Öğretmenlerinin Görüşlerine Göre Değerlendirilmesi 
Üstün zekâlıları tanılamak için kullanılan zekâ testleri de sosyoekonomik olarak zayıf ailelerden gelen öğrenciler için dezavantaj oluşturabilmektedir. Öğrencilerin zekâ testlerindeki performansları, yaşantı zenginliklerine ve yaşamdaki öğrenme firsatlarına da bağlıdır. Bu nedenle yaşam boyu öğrenme ortamı zayıf olan çocukların zekâ testlerinde de düşük performans göstermeleri büyük bir olasılıktır. Hatta bu çocukların birçoğu zekâ testlerinde yer alan bazı maddeleri yaşamları boyunca hiç deneyim edinmemiş bile olabilirler. Örneğin popüler zekâ testlerinden birinin önceki sürümlerinden birinde piyano ile ilgili bir soru yer almaktadır. Bütün çocukluğu boyunca hiç piyano görmemiş bir çocuğun bu soruyu yanıtlaması pek olası değildir. Kısacası Özel yetenekli öğrencileri tanılama sürecinde, öğrencilerin sosyoekonomik ve kültürel farklılıkları incelenmeli ve sosyoekonomik olarak zayıf ailelerden gelen çocukların performansları çok yönlü değerlendirilmelidir (Sak, 2014).

Son yıllarda özellikle 1990’lı yıllardan itibaren Milli Eğitim Bakanlığı'nın ve üniversitelerin Zekâ testlerine ilişkin yeni çalışmaları dikkat çekmektedir. Her ne kadar eski versiyonu da olsa WISC-R'ın Türk çocukları üzerinde standardizasyonu Savaşır ve Şahin (1995) tarafından gerçekleştirilmiştir. Ayrıca Raven Standart Progresif Matrisler Testi'nin (RSPM) 6-15 yaş grubundaki Türk çocukları için standardizasyon çalışması, Şahin ve Düzen (1993) tarafından yapılmıştır. Wechsler Sözel Olmayan Yetenek Testi'nin (WNV) 2006 versiyonu ile Kaufman Kısa Zekâ Testi'nin (KBIT) 2004 versiyonunun Türkiye norm çalışması MEB tarafından 2014 yılında yapılmıştır (MEB, 2014). Zekâ testleri alanında Türkiye'de yapılmış en önemli çalışma ise ilk yerli Zekâ ölçeğinin geliştirilmesi ve norm çalışmasıdır. Anadolu Üniversitesi Üstün Yetenekliler Eğitimi Uygulama ve Araştırma Merkezi (ÜYEP) araştırmacılarının oluşturduğu ekip tarafından Anadolu-Sak Zekâ Ölçeği (ASİS) geliştirilmiş, 2016 yılı itibari ile norm çalışmaları tamamlanmış ve 2017 yılı itibariyle de MEB tarafından ülke genelinde kullanılmaya başlanmıştır (Öpengin, 2019).

Değerlendirme sürecinde kullanılan ölçme araçları kültürden ve dilden bağımsız geliştirilmelidir. Diğer bir deyişle, kullanılan araçlar değerlendirilen bireylerin ana dilinde hazırlanmalıdır ve kültürüne uygun olmalıdır. Aynı zamanda göçmen ailelerin çocukları, sosyal ve ekonomik olarak dezavantajlı gruplar içerisinde yer alan veya farklı kültürlerden gelen çocukların ölçümüne de duyarlı araç/yöntemler tercih edilmelidir. Özel yeteneklilerin Eğitimi Ortak Akıl Platformu Raporu'nda tanılama sorunu olarak; tanılama için geçerli, güvenilir, kültüre uygun ölçme araçları geliştirilmesinin özel yeteneklilerin eğitimi uygulamasında önümüzdeki 
yıllarda görmek istenilen en önemli somut durum olarak ifade edilmiştir (Türkiye Bilimsel ve Teknolojik Araştırma Kurumu [TÜBİTAK], 2010).

Tanılama araçlarının ölçtükleri yetenek ile eğitim programlarının içeriklerinin örtüşmemeleri tanılama sürecinin geçerliliğini olumsuz etkileyen önemli bir sorundur. Bu sorun çoğu zaman programa yanlış öğrenci tanılandığında fark edilir. Öğrencilerin programdan yarar sağlayamamalarının veya programda başarısız olmalarının altında yatan en önemli etmenlerden biri tanılama sistemi ve eğitim programı arasında var olan uyumsuzluktur (Sak, 2014). Tanılama öğrencilerin özelliklerini belirlemek ve elde edilen sonuçlardan hareketle öğrencilerin eğitimine yön vermek amacı ile yapılır. Ölçme araçlarından elde edilen sonuçlara göre öğrencilerin ileri oldukları alanlarda daha çok gelişmelerini sağlayacak etkinliklere yer verilirken daha az gelişmiş alanlarının da geliştirilmesini sağlayıcı eğitim etkinlikleri düzenlenir. Hâlbuki ülkemizde tanılama işlemlerinin sadece öğrenci seçme amacı ile yapıldığı görülmektedir (Kurnaz, 2014).

Erken tanılanamama, bir diğer problem durumudur. Erken ve doğru tanılama eğitsel ihtiyaçlarını belirlemede ilk adımdır. Öğrencilere yetenek ve potansiyellerini geliştirebilecekleri eğitim ortamlarının sağlanması bağlamında önem taşımaktadır. Ancak, çocuğun yetenek yelpazesi henüz billurlaşmadığından dolayı okul öncesi dönemde tanılamada kullanılan yöntemlerin geçerlik ve güvenilirliği oldukça düşüktür (Ataman ve diğerleri, 2014; MEB, 2009). Okul öncesi öğretmenleriyle yapılan çalışmalar, öğretmenlerin anne babalara göre özel yetenekli çocukları fark etmede güçlük çektiklerini, öğretmenlerin değerlendirmelerinin tek başına kullanılmasının doğru yöntem olmadığını ortaya koymaktadır. Bu durumun nedeni olarak, öğretmenlerin bebeklik ve okul öncesi döneme ilişkin özel yeteneklilik ile ilgili yanlış ya da yetersiz bilgileri ve tutumları gösterilmektedir (Dönmez, 2014).

Ülkemizde özel yetenekli çocukların tanılanma süreciyle ilgili nitel ve nicel birçok problem yaşanmaktadır. Tanılamada ilk sorun küçük yaştaki (2-4 yaşları) özel yetenekli çocuklarımızın tespit edilmesi sürecinde yaşanmaktadır. Bu öğrenciler tanılama yapabilecek yetkili kurumlara ulaşamadığı gibi ulaşanlar için de çok küçük yaştaki özel yetenekli çocuklarımızı tanılayacak ölçme araçları yeterli değildir (Kurnaz, 2014; MEB, 2009). Özel yetenekli çocuklarda erken ve doğru tanılama eğitsel ihtiyaçlarını belirlemede ilk adımdır. Özel yetenekli öğrencilere yetenek ve potansiyellerini geliştirebilecekleri eğitim ortamlarının sağlanması bağlamında önem taşımaktadır. Ancak, çocuğun yetenek yelpazesi henüz billurlaşmadığından dolayı okul öncesi dönemde tanılamada kullanılan

BİLSEM Tanılama Sürecinde Kullanılan Zeka Testlerinin Psikolojik Danısmanların ve BİLSEM Öğretmenlerinin Görüşlerine Göre Değerlendirilmesi 
yöntemlerin geçerlik ve güvenilirliği oldukça düşüktür (Ataman ve diğerleri, 2014). Okul öncesi öğretmenleriyle yapılan çalışmalar, öğretmenlerin anne babalara göre özel yetenekli çocukları fark etmede güçlük çektiklerini, öğretmenlerin değerlendirmelerinin tek başına kullanılmasının doğru yöntem olmadığını ortaya koymaktadır. Bu durumun nedeni olarak, öğretmenlerin bebeklik ve okul öncesi döneme ilişkin özel yeteneklilik ile ilgili yanlış ya da yetersiz bilgileri ve tutumları gösterilmektedir (Dönmez, 2014).

İlkokul dönemindeki özel yetenekli öğrencilerin tanılanmasında da önemli sorunlar vardır. Bu konudaki en önemli sorun ülkemizde kendi kültürümüze has, güncel ve güvenirliği yüksek tanılama araçlarından yoksun oluşumuzdur. Burada sorun bir ölçme aracının kendi kültürümüze has olmasından çok ölçme araçlarını kendimiz üretmediğimiz için araçların güncellenmesinin güçleşmesindedir (Kurnaz, 2014; MEB, 2009). Diğer bir sorun da tanılama sürecinde sadece aday gösterilen öğrencilerin birtakım testlere tabi tutularak seçilmesi durumunun sınıf öğretmenlerinin inisiyatifine bırakılmasına neden olmaktadır. MEB (2010) İç Denetim Birimi Başkanlığı Bilim ve Sanat Merkezleri Süreci (Özel yetenekli Bireylerin Eğitimi) İç Denetim Raporu anket uygulamasında, ankete katılanların büyük bir çoğunluğu, okullardaki öğretmenlerin, özel yetenekli veya özel yetenekli öğrencilerin ayırt edici özellikleri konusunda yeterince bilgi sahibi olmadığı görüşünde birleşmektedir. Böyle bir riskin bulunması, aday gösterilebilecek durumda olan öğrencilerin aday gösterilmeyerek mağdur olmasına neden olabilmektedir.

Özel yetenekli öğrencilerin tanılama sürecinde birden fazla kaynaktan bilgi toplanması son derece önemlidir. Örneğin, zekâ testleri özel yetenekli öğrencilerin \%60'ını, öğretmenler \%45'ini, yaratıcılık testleri \%10'unu, akademik başarı testleri \%60'ını doğru olarak tanılayabilmektedir. Zekâ testlerinin ve başarı testlerinin birlikte kullanıldığı tanılama uygulamalarında ise doğru tanılama oranı \%90'a kadar çıkabilmektedir (Sak, 2011). Buna karşın, ülkemizde üstün zekâlı/yetenekli çocukların belirlenmesi genel itibariyle, Rehberlik ve Araştırma Merkezi'nde (RAM) ya da BILLSEM'de yapılan bireysel zekâ testi sonuçlarına göre yapılmaktadır. Oysa Özel yetenekliliğin, önceden olduğu gibi sadece "zekâ bölümünde üstünlük" (130 ve yukarısı) kriterine dayalı olarak tanılanması, diğer zihinsel değerlendirmelerde de geçerli olduğu gibi çocuk açısından önemli dezavantajlar taşımaktadır. Çünkü böyle kısıtlı bir değerlendirmede, henüz zekânın çeşitli boyutlarını yeterince kapsayıp kapsamadığı bile kesinleşmemiş olan ölçekler, sadece normal zihin düzeyi temel alınarak yapılandırılmıştır (Levent, 2011). 
Tanılama ile ilgili nicel sorunlar da vardır. Ülkemizde 350-400 bin özel yetenekli öğrenci varken sadece 24.291 (MEB, 2017) öğrenciyi tanılayabilmiş olmamız bunun en açık göstergesidir. Tanılama sürecinde ülkemizdeki birkaç şehir dışında pek çok ilimizde sadece şehir merkezindeki çocuklar belirli bir sınıf düzeyinde tanılamaya alınmakta, her sınıftan belirli sayıda öğrencinin (1-3) aday gösterilmesi dolayısıyla tüm öğrencilerin taramalara katılamamaktadır. Sorun aday gösterilen öğrenciler açısından da devam etmektedir. Örneğin grup taramalarında temel kabiliyetler testinde \%75'lik dilimin üzerinde yer alan her öğrenciye bireysel zekâ testi uygulanması gerekirken, bireysel zekâ testi sadece o ildeki BİLSEM' in belirttiği kontenjanın üç katı kadar öğrenciye uygulanabilmektedir. Bu da aynı sınıf çağında bir il için en fazla 100-150 öğrencinin bireysel tanılamaya alınmasına sebep olmaktadır. Böylece şehir merkezlerindeki çocukların çok büyük bir bölümü tanılamaya dâhil olamamaktadır. Durum ilçe, kasaba ve köylerdeki çocuklar için daha vahimdir. Bu çocuklar için böyle bir tanılama süreci bile söz konusu değildir (Kurnaz, 2014).

Ülkemizde çok uzun bir süredir WISC-R testinin kullanılmış olması, bu testin ilk uyarlamasının üzerinden çok uzun bir zaman geçmiş olması uzmanlar, tanılama testlerini uygulayan psikolojik danışmanlar, özel yetenekli öğrencilere eğitim veren öğretmenler ve veliler arasında pek çok soru işareti ve belirsizlikler oluşmasına sebep olmuştur. Bununla birlikte WNV testinin 2015 yılında henüz yeni kullanılmaya başlanmış olması, bu testin sözel alt boyutunun olmaması başka soru işaretleri doğurmuştur. Tanılama süreci ve sonuçlarına ilişkin veliler, okullardaki öğretmenler ve BİLSEM öğretmenleri arasında pek çok konu tartışılmasına rağmen bu tartışmaların hiç birisi bilimsel araştırma sonuçlarına dayalı değildir. Tanılama sürecinde testleri uygulayan psikolojik danışmanların ve bu testlerle seçilen öğrencilerle çalışan öğretmenlerin görüşlerinin tanılama sürecine ve araçlarına ilişkin görüşlerinin bu soruları açıklığa kavuşturabileceği düşünülmektedir. Bu kapsamda aşağıdaki sorulara cevap aranmıştır;

1. WISC-R testi ve uygulama süreciyle ilgili psikolojik danışmanların görüşleri nasıldır?

2. WISC-R Testi yerine WNV Testinin uygulanıyor olması ile ilgili psikolojik danışmanların görüşleri nasıldır?

3. WNV Testinin, grup tarama tablet testinde başarılı olan öğrencilere uygulanma süreci ile ilgili psikolojik danışmanların görüşleri nasıldır?

4. WISC-R Zekâ Testi ve WNV Testinin üstün zekâyı ayırt etme gücü ile ilgili psikolojik danışmanların görüşleri nasıldır?

BİLSEM Tanılama Sürecinde Kullanılan Zeka Testlerinin Psikolojik Danışmanların ve BİLSEM Öğretmenlerinin Görüşlerine Göre Değerlendirilmesi 
5. BİLSEM öğretmenlerine göre BİLSEM'e kabul yaşı kaç olmalıdır?

6. BİLSEM öğretmenlerinin görüşlerine göre TKT ile tanılanarak gelen öğrencilerle son üç yılda uygulanan grup tarama testi ile gelen öğrencilerin etkinliklerdeki performansları arasındaki farklılıklar nelerdir?

7. BİLSEM öğretmenlerinin görüşlerine göre TKT ile tanılanarak gelen öğrencilerle son üç yılda uygulanan grup tarama testi ile gelen öğrencilerin BILLSEM'e uyumları arasındaki farklılıklar nelerdir?

8. BİLSEM öğretmenlerinin tanılama süreciyle BİLSEM'lere kabul edilen öğrencilerin doğru seçilip-seçilmediğiyle ilgili görüşleri nasıldır?

9. BİLSEM öğretmenlerinin özel yeteneklileri tanılama sürecinde kullanılan zekâ testleriyle ilgili görüşleri nasıldır?

10. BİLSEM öğretmenlerinin tanılama sürecine ilişkin önerileri nelerdir?

“Özel yetenekli çocukların tanılanması, onlara uygun eğitim olanaklarının sunulması açısından büyük önem taşımaktadır." ilkesinden yola çıkarak bu araştırmada, özel yetenekli öğrencilerin tanılanması sürecinde yaşanan olumlu ve olumsuz yönleri belirleyerek tanılama süreci ile ilgili mevcut durum tespiti yapmak hedeflenmektedir. Araştırma ile özel yetenekli öğrencilerin tanılanma süreci ile sürece dâhil olan psikolojik danışmanların bu sürece ilişkin görüşleri ortaya konulmaya çalışılmıştır. Ayrıca tanılama sürecinde farklı yöntemlere göre seçilen öğrencilerin BİLSEM'lerdeki performanslarını ortaya koymak için BİLSEM öğretmenlerinin görüşlerine başvurulmuştur. Araştırma sonuçlarının gelecekte yapılacak uygulamaların daha sağlıklı yürümesine katkı sağlayacağı ve alan yazındaki eksikliği gidereceği düşünülmektedir.

\section{Araştırmanın Amacı ve Önemi}

Tanılama ne kadar sağlıklı yapılırsa, üstün zekâlı/yetenekli öğrencilerin uygun eğitim alarak yeteneklerini geliştirme imkânı daha iyi olacaktır. Bu araştırmada da ülkemizde üstün zekâlı/yetenekli bireylerin tanılanması konusunda durum tespiti yapılarak iyileştirici öneriler sunulduğu için araştırmanın önemini arttırmaktadır. Tanılama işlemi, aday gösterme, grup testleri uygulama, bireysel inceleme ve yönlendirme aşamalarından oluşmaktadır. Bu süreçteki aksaklıkları belirlemek olumlu ve olumsuz yönleri tespit etmek gelecekte yapılacak uygulamaların daha sağlıklı 2020/2 yürümesine katkı sağlayacağı için konunun önemini arttırmaktadır. Ülkemizde üzerinde mutabık kalınmış bir tanılama yöntemi yoktur. 
Özel Eğitim ve Rehberlik Hizmetleri Genel Müdürlüğü tarafından her yıl belirlenen sınıf seviyesine ve uygulama takvimine göre yapılan seçimler sırasında farklı uygulamalarla karşılaşılmaktadır. Üstün zekâlı/yetenekli çocukların tanılanma sürecinin netleştirilmesine ve yeni bir tanılama sistematiği oluşturma sürecinde paydaşların görüşlerine ihtiyaç vardır.

Üstün zekâlı/yetenekli çocukların tanılama sürecindeki aksaklıkları belirlemek olumlu ve olumsuz yönleri tespit ederek gelecekte yapılacak uygulamaların daha sağlıklı yürümesine katkı sağlamak için, ülkemizde özel yeteneklilerin tanılanma sürecinin netleştirilmesi gerekmektedir. Üstün yeteneğin tanılanmasında öğretmen, ebeveyn ve ilgili uzmanlardan kurulacak bir ekip birlikte çalışarak gerekli verileri toplar. Bu ekip; öğretmen saptamaları, çocukla ilgili tutulan çeşitli kayıtlar, aile görüşmeleri, çocuğun yaşıtlarıyla görüşme, çocukla görüşme, biyografik veriler, anekdot kayıtları, çocuğun ürünleri ve uzman görüşleri ışığında gerekli verileri toplar. Uzman kişiler bu aşamadan sonra grup zekâ testleri, bireysel zekâ testleri, yaratıcılık testleri, kritik düşünme testleri veya resim-müzik gibi alanlar için özel testleri uygulayarak bir sonuca varırlar (Eker, Kurnaz ve Sarı, 2017). Yeni bir tanılama sistematiği oluşturma sürecinde de Psikolojik Danışman (PD) ve BİLSEM öğretmenlerinin görüşlerinin ortaya konulabilmesi için bu araştırmaya ihtiyaç vardır. Bu araştırmanın genel amacı, ülkemizde özel yetenekli öğrencilerin tanılanması sürecinde yaşanan olumlu-olumsuz yönleri belirleyerek, tanılama sürecinin netleştirilmesine yardımcı olmak, süreç içerisinde öğretmenlerin ihtiyaçlarını belirlemektir. Bu sayede öğretmenlerin hangi konularda desteğe ihtiyaç duyduğu ve tanılama sürecinin daha sağlıklı yürütülebilmesi için hangi önlemlerin alınabileceği belirlenmiş olacaktır. Yapılan görüşmelerden elde edilen sonuçlara göre, tanılama sürecinin eksiklikleri tespit edilebilecek ve çözüme yönelik öneriler geliştirilebilecektir.

\section{Yöntem}

\section{Araştırmanın Modeli}

$\mathrm{Bu}$ araştırmada, nitel araştırma yöntemlerinden durum çalışması deseni kullanılmıştır. Nitel durum çalışmasının en temel özelliği bir ya da birkaç durumun derinliğine araştırılmasıdır. Yani bir duruma ilişkin etkenler (ortam, bireyler, süreçler, vb.) bütüncül bir yaklaşımla araştırılır ve ilgili durumu nasıl etkiledikleri ve ilgili durumdan nasıl etkilendikleri üzerine odaklanilir.

Araştırmada durum çalışması desenlerinden biri olan iç içe geçmiş çoklu durum deseni uygulanmıştır. Bu desende birden fazla durum söz

BİLSEM Tanılama Sürecinde Kullanılan Zeka Testlerinin Psikolojik Danışmanların ve BİLSEM Öğretmenlerinin Görüşlerine Göre Değerlendirilmesi 
konusudur. Ancak ele alınan veya araştırmaya dâhil edilen her bir durum kendi içinde de çeşitli alt birimlere ayrılarak çalışılabilir ve veriler birbiriyle karşılaştırılabilir (Şimşek ve Yıldırım, 2013). İlk aşamada araştırma soruları ve araştırmanın alt problemleri geliştirilmiştir. Özel yeteneklileri tanılama sürecinde aktif rol oynayan, bu süreci etkileyen ve bu süreçten etkilenen her grup (aday gösteren sınıf öğretmeni, aday gösterilen öğrenci, öğrenci velileri, testi uygulayan psikolojik danışman, BİLSEM öğretmeni) birer analiz birimi olarak düşünülmüş ve araştırmaya katılacak bireyler seçilmiştir. Sonraki aşamada veriler toplanmış ve toplanan veriler alt problemlerle ilişkilendirilmiştir. Son aşamada ise veriler analiz edilmiş ve yorumlanmıştır.

\section{Katılımcılar}

Nitel araştırmada örneklem seçimi nicel araştırmaya göre bir ölçüde farklılık gösterir. Her şeyden önce nitel araştırmada örneklemin geniş olması çoğu zaman mümkün değildir. Gerek araştırma kaynaklarının sınırlılığı gerekse kullanılan bilgi toplama ve analiz yöntemlerinin özelliği nedeniyle çok sayıda bireyi araştırma örneklemine dâhil etmek gerçekçi olmaz. Bazen bir birey tek başına bir araştırmanın örneklemini oluşturabilir. Bu nedenle nitel araştırmalarda geçerli olabilecek ve her araştırmaya uyabilen örneklem belirleme yöntemleri sunmak mümkün değildir. Yine de nitel araştırmalarda yaygın olarak kullanılan bazı örneklem belirleme yöntemleri mevcuttur. Bu yöntemlerden amaçlı örnekleme yöntemi, zengin bilgiye sahip olduğu düşünülen durumların derinlemesine çalışılmasına olanak vermektedir.

Bu araştırmada, amaçlı örnekleme yöntemlerinden ölçüt örnekleme yöntemiyle katılımcılar seçilmiştir. Bu örnekleme yöntemindeki temel anlayış önceden belirlenmiş bir dizi ölçütü karşılayan bütün durumların çalışılmasıdır. Burada sözü edilen ölçüt veya ölçütler araştırmacı tarafından oluşturulabilir ya da daha önceden hazırlanmış bir ölçüt listesi kullanılabilir (Şimşek ve Yıldırım, 2013).

Bu araştırmanın katılımcıları, 2015 yılında BİLSEM seçmeleri için özel yeteneklileri tanılama sürecine dâhil olan 15 psikolojik danışman oluşturmaktadır. Psikolojik danışman katılımcıların belirlenmesindeki ölçüt, grup tarama tablet testinde (GTTT) başarılı olan öğrencilere WNV testi uygulamış olmasıdır. Psikolojik danışman katılımcıların 3'ü kadın, 12'si erkektir. Katılımcıları seçerken ölçüt örnekleme yöntemi kullanılarak tanılama sürecinde aktif olarak yer almaları ölçüt alınmıştır. Katılımcılar Türkiye geneli her bölgeyi temsil edecek şekilde Samsun, Sinop, Kastamonu, Sakarya, Bursa, Yalova, Kayseri, Siirt, Mersin, Afyon, Diyarbakır, Sivas ve 
Van illerindendir. Katılımcılar BİLSEM seçme sürecinde en az iki, en çok 7 yıl görev almıştır. Psikolojik danışmanlar bulgular bölümünde (PD) kodu ile kodlanmıştır.

Katılımcıların arasında yer alan BİLSEM öğretmenlerinin belirlenmesindeki ölçüt ise öğretmenlerin Bilim ve Sanat Merkezinde görev yapıyor olmalarıdır. Araştırmaya katılan BİLSEM öğretmenlerin çalışma gruplarına göre dağılımı Türkçe öğretmenliği grubu 3, Sınıf öğretmenliği grubu 3, Sosyal öğretmenliği grubu 3, Fen öğretmenliği grubu 2, Psikolojik Danışman grubu 7 olarak toplam 22 görülmektedir. Katılımcılar Türkiye geneli her bölgeyi temsil edecek şekilde Samsun, Sinop, Kastamonu, Sakarya, Bursa, Yalova, Kayseri, Siirt, Mersin, Afyon, Diyarbakır, Sivas ve Van illerindendir. Katılımcıların BİLSEM'de çalışma süreleri 3 ile 8 yıl arasında değişmektedir. Katılımcıların görev yerleri farklılık göstermekle beraber meslekteki yılların ve BILLSEM'de çalışma sürelerinin farklılık göstermesi açısından araştırmaya katkı sağlayacağı düşünülmektedir. BİLSEM öğretmenleri bulgular bölümünde (B) kısaltması ile kodlanmıştır.

\section{Veri Toplama Araci}

Araştırmanın kuramsal temelini oluşturabilmek ve uygun veri toplama araçlarını geliştirebilmek için ilgili literatür incelenmiş ve yasal mevzuat taranmıştır. Ülkemizde özel yetenekli öğrencileri tanılama süreçleri araştırılarak tanılamanın; tarama, bireysel inceleme-değerlendirme ve yönlendirme aşamaları olmak üzere üç bölüme ayrıldığı ve bu aşamaların BİLSEM seçmelerinde uygulandığı gözlenmiştir. Necmettin Erbakan Üniversitesinden alanda uzman akademisyenlerle görüşülmüş, çeşitli illerdeki Rehberlik Araştırma Merkezi ve BİLSEM idareci ve test uygulayan psikolojik danışmanlar ile görüşmeler gerçekleştirilerek tanılama sürecinde yaşadıkları sıkıntılar dinlenmiştir. Edinilen bilgilerden yola çıkılarak taslak görüşme soruları hazırlanmıştır. Hazırlanan sorular uzman görüşlerine sunulmuş ve gerekli değişiklikler yapılarak açık uçlu sorulardan oluşan bir görüşme formu oluşturulmuştur. Oluşturulan form 6 öğretmene deneme amaçlı uygulanmış ve formlara nihai şekli verilmiştir. Psikolojik danışmanlar BİLSEM olan illerden seçilmiş ve gönüllülük esas alınarak görüşmeler gerçekleştirilmiştir. BİLSEM öğretmenlerine uygulanan görüşme formları ise 6-10 Nisan 2015 tarihleri arasında Antalya'da düzenlenen 'Bilim ve Sanat Merkezlerinde Uygulanan Etkinliklerin Geliştirilmesi, Zenginleştirilmesi ve Standardizasyonu Çalıştayı sırasında 2020/2 grup masalarında gönüllüliük esasına göre bireysel ya da odak grup görüşmesi şeklinde uygulanmıştır.

BİLSEM Tanılama Sürecinde Kullanılan Zeka Testlerinin Psikolojik Danışmanların ve BİLSEM Öğretmenlerinin Görüşlerine Göre Değerlendirilmesi 
Psikolojik danışman ve psikolojik danışmanlara BİLSEM tanılama sürecinde uygulanan WISC-R ve Wechsler Nonverbal Yetenek (WNV) testlerine ve uygulama sürecine ve sonuçlarına ilişkin görüşleri sorulmuştur. BILLSEM öğretmenlerine de tanılama sürecine, BİLSEM'e kabul yaşına, grup tanılama sürecinde TKT ile seçilen öğrenciler ile tablet uygulamasına dayalı seçilen öğrencilerin farklılıklarına, BILLSEM'lere kabul edilen öğrencilerin doğru seçilmesine ilişkin görüşleri sorulmuştur.

\section{Verilerin Analizi}

Verilerin analizi aşamasında, betimsel analiz ve içerik analizi yöntemi birlikte kullanılmıştır. Betimsel analizde amaç, elde edilen bulguları düzenlenmiş ve yorumlanmış bir biçimde okuyucuya sunmaktır. Bu amaçla elde edilen veriler, önce sistematik ve açık bir biçimde betimlenir. Daha sonra yapılan bu betimlemeler açıklanır ve yorumlanır, neden-sonuç ilişkileri irdelenir ve birtakım sonuçlara ulaşılır. İçerik analizinde ise temel amaç, toplanan verileri açıklayabilecek kavramlara ve ilişkilere ulaşmaktır. Betimsel analizde özetlenen ve yorumlanan veriler, içerik analizinde daha derin bir işleme tabi tutulur ve betimsel bir yaklaşımla fark edilemeyen kavram ve temalar bu analiz sonucu keşfedilebilir (Şimşek ve Yıldırım, 2013).

Nitel araştırmalarda sonuçların inandırıcılığını, geçerliliğini ve güvenilirliğini arttırmaya yönelik önemli stratejilerden biri de veri çeşitlemesidir. Daha çok veri toplama yöntemleri ile ilişkilendirilen çeşitleme kavramı, aynı zamanda örneklem çeşitlemesi, analiz çeşitlemesi gibi farklı boyutlarda da kullanılabilmektedir (Şimşek ve Yıldırım, 2013). Bu araştırmada da sonuçların geçerlik ve güvenirliliğini arttırmak için çeşitleme yoluna gidilmiştir. Tanılama süreci içindeki farklı gruplarla görüşülmüuş, görüşülen birey sayısı her bölgeyi temsil edecek şekilde arttırılmış, ayrı gruplara uygulanan anket sonuçları önce kendi aralarında karşılaştırılmış sonra alanda yapılan benzer araştırma sonuçlarıyla kıyaslanmış, görüşülen bireylerden doğrudan alıntılara yer verilmiştir. Verilerin analizinin güvenirliliğini sağlamak için araştırmacı ve başka bir uzman olmak üzere iki kişi tarafından veriler analiz edilmiş ve analizde görüş birliği sağlanan hususlar araştırmaya dâhil edilmiştir.

Araştırmada aşağıda yer alan kriterler göz önüne alınarak geçerlilik ve güvenirlik sağlanmaya çalışılmıştır: Araştırma yöntemi ve yöntem altında yer alan veri toplama veri analizi bölümleri detaylıca anlatılmıştır. Araştırma katılımcıları amaçlı örneklem yöntemi ile belirlenmiştir. Araştırma katılımcılarına araştırmacılar tarafından geliştirilen yarı yapılandırılmış görüşme formunda yer alan sorular sorulmuştur. 
Katılımcıların gönüllülüğü esasa alınmıştır. Yapılan görüşmeler katılımcıların onayına sunularak analiz edilmiştir. Araştırma verileri betimsel ve içerik analizine uygun şekilde analiz edilmiştir.

Araştırma verilerinin kodlaması iki araştırmacı tarafından farklı zamanlarda ikişer kez gerçekleştirilmiştir. Kodlayıcılar tarafından kodlanan veri setinin, benzerlik oranı önemlidir (Fidan ve Öztürk, 2015a). Bu benzerlik oranı aynı zamanda nitel araştırmanın güvenirliğini belirlemektedir. Miles ve Huberman modelinde içsel tutarlılık olarak adlandırılan ve kodlayıcılar arasındaki görüş birliği olarak kavramsallaştırılan bu benzerlik bir formül kullanılarak hesaplanabilir. Formülde, Güvenirlik katsayısı= Üzerinde görüş birliği sağlanan terim sayısı / (Üzerinde görüş birliği sağlanan terim sayısı + Üzerinde görüş birliği bulunmayan terim sayısı) X 100 formülü ile hesaplanır. İçsel tutarlılığı veren kodlama denetimine göre kodlayıcılar arası görüş birliğinin en az \% 80 olması beklenmektedir (Miles ve Huberman, 1994; Patton, 2002). Bu araştırmada da veri analizleri ve kodlanması iki araştırmacı tarafından gerçekleştirilmiş ve kodlayıcılar arası uyuma bakılmıştır. Kodlayıcılar arası güvenirlik katsayısı 0,86 olarak hesaplanmıştır. Buna göre verilerin analizinde güvenirliğin sağlandığı görülmektedir.

\section{Bulgular ve Yorum}

\section{Psikolojik danışmanlardan Elde Edilen Bulgular}

Önceki yıllarda BİLSEM tanılama sürecinde kullanılan "WISC-R testi ve uygulama süreciyle ilgili görüşleriniz nelerdir?” sorusuna psikolojik danışmanlar sadece testlerin özellikleriyle ilgili cevaplar vermişler ve uygulanma sürecine yönelik cevaplar vermemişlerdir. Psikolojik danışmanların verdikleri cevapların sıklık dağılımları Tablo 1'de verilmiştir. Tablo incelendiğinde tanılama sürecinde WISC-R zekâ testine yönelik öğretmen görüşlerinde önemli noktalardan bir tanesi işlevsel, geçerli ve güvenilir (\%24) olması gelmektedir. PD7 kodlu psikolojik danışman "WISC-R testinde alt test sayısı daha fazla olduğundan ve performansın yanında sözel zekâyı ölçmeye yönelik daha fazla alt testi olduğundan güvenirlik ve geçerliliğinin daha iyi olabileceği düşünülmektedir." şeklinde bu düşünceyi ifade etmiştir. Başka bir psikolojik danışman ise komplike ve kapsamlı olmasını (\%20) şu şekilde açıklamıştır: WISC-R testinin kapsamlı şekilde birçok beceriye dayalı performans ölçümü yapması açısından daha genel geçer bir sonuç verdiğini; ancak özellikle sözel alt testlerde revizyona gereksinim duyulduğunu düşünüyorum" (PD15).

BİLSEM Tanılama Sürecinde Kullanılan Zeka Testlerinin Psikolojik Danışmanların ve BİLSEM Öğretmenlerinin Görüşlerine Göre Değerlendirilmesi 
Tablo 1. Psikolojik Danışmanların Tanılama Sürecinde Tanılama Sürecinde WISC-R Testi Kullanımına İlişkin Görüşleri

\begin{tabular}{|l|c|c|}
\hline Tanılama Sürecinde WISC-R Testi & f & $\mathbf{\%}$ \\
\hline İşlevsel, geçerli ve güvenilir & 6 & 24 \\
\hline Komplike- kapsamlı olması & 5 & 20 \\
\hline Uzun, Zaman Alıcı ve Zorlayıcı & 4 & 16 \\
\hline Ulaşılmasının Kolay Olması & 4 & 16 \\
\hline İşlevsel, geçerli ve güvenilir değil & 3 & 12 \\
\hline Revizyon yapılmalı & 3 & 12 \\
\hline Toplam & 25 & 100 \\
\hline
\end{tabular}

Psikolojik danışmanların dikkat çektiği bir diğer nokta ise WISC-R testinin uzun, zaman alıcı ve zorlayıcı (\%16) bir test olmasıdır. PD3 kodlu öğretmenin ifadesi şu şekildedir: "WISC-R uygulama sürecinde bulunduğum süreç boyunca bu testin kendi doğasindan kaynaklanan herhangi bir sorun yaşamadım. Test hem uygulayıcı hem de öğrenci için süre açısından daha komplike. Dikkat, kayıtlama, süre tutma ve eşgüdümlü olması gerektiğinden yorucu. Günde üçten fazla test almak hayli yorucu oluyordu". Bu konuda PD8 kodlu öğretmen de "Önceki yıllarda kullanılan testlerden yapma imkânım olmadı. Ancak bazı öğretmen ve velilerin içeriğine ulaşılabilirliği kolay olduğu bilinen bu testlere, öğrencileri çalıştırarak başarılı olmalarına yönelik gayret sarf ettikleri bilinen bir husustur. Özellikle WISC-R testinin WNV testine göre uzun zaman sürdüğ̈̈ görülmektedir." If fadesinde bulunmuştur.

Bazı öğretmenler ise WISC-R testinin ulaşılmasının kolay olması (\%16) ve Revizyon yapılması (\%12) gerektiğine değinmiştir: "WISC-R uygulayıcısı değilim ama bugün internet sitesinden; yeterliliği olmayan birisi bile sipariş verip bu testin materyallerine sahip olabilmektedir. Bu durum WISC-R testinin geçerliliğini düşürmektedir” (PD2). Başka bir öğretmen ise bu ifadeyi şu şekilde desteklemiştir: "WISC-R testinin kapsaml bir şekilde birçok beceriye dayalı performans ölçümü yapması açısından daha genel geçer bir sonuç verdiğini ancak özellikle sözel alt testlerde revizyona gereksinim duyulduğunu düşünüyorum."

PD14 kodlu psikolojik danışman ifadesi ise şu şekildedir: "WISC-R testinin piyasada çok fazla dolaşması hatta Google da bile bazı sorularının bulunabilmesi bu testin objektifliğini kaybettirmişti. Ayrıca bazı çocukların testin bölümlerini öğrenebilmesi de testin işlevselliğini kaybettirmişti."

Zekâ testi uygulayan psikolojik danışmanlardan alınan görüşler incelendiğinde, öğretmenlerin çoğunluğu testin uygulamasının uzun 
zaman aldığını, zorlayıcı olduğunu, ulaşılabilirliğinin arttığını bu yüzden güvenirliliğini yitirdiği ve revizyona ihtiyacı olduğunu belirtmişlerdir. Önemli bölümü ise WISC-R testini işlevsel, geçerli, güvenilir ve daha kapsamlı bulmaktadırlar.

"BILLSEM tanılama sürecinde bu yıldan itibaren WISC-R Testi yerine WNV Testinin uygulanacak olması ile ilgili görüşleriniz nelerdir?" sorusuna psikolojik danışmanların verdikleri cevapların sıklık dağılımları Tablo 2'de verilmiştir.

Tablo 2. Psikolojik Danışmanların Tanılama Sürecinde WNV Testi Kullanımına İlişkin Görüşleri

\begin{tabular}{|l|c|c|}
\hline Tanılama Sürecinde WNV Testi & f & \% \\
\hline Geçerliği ve güvenirliği yüksek & 9 & 20,45 \\
\hline İşlevsel, kısa süreli ve Pratik Olması & 8 & 18,18 \\
\hline Güncel ve Orijinal Olması & 7 & 15,91 \\
\hline Sözel Bölümün Ölçülmesi Eksik & 7 & 15,91 \\
\hline Sorulara Ulaşılmasının Zor olması & 4 & 9,09 \\
\hline Kullanımın Kolay Olması & 4 & 9,09 \\
\hline $\begin{array}{l}\text { Yetenek ve Performans Belirlemeye Yönelik } \\
\text { Olması }\end{array}$ & 3 & 6,82 \\
\hline Görsel Algıyı Ölçer & 2 & 4,55 \\
\hline Toplam & 44 & 100 \\
\hline
\end{tabular}

Tablo incelendiğinde tanılama sürecinde WNV testine yönelik psikolojik danışmanların görüşlerinde genellikle olumlu yanıtlar verdikleri görülmekte olup \% 15,91 ile testin sözel bölümünün eksik oluşu olumsuz bulunmaktadır. Psikolojik danışmanlar WNV testinin geçerlilik ve güvenirliğinin yüksek olduğunu ifade etmiştir. "WNV Testinin WISC-R Testi kadar alt ölçeğinin bulunmaması, kapsamlılığı açısından bir eksiklik olmakla birlikte daha pratik ve ekonomik bir test olması yönüyle avantajlıdır. Güncel ve orijinal olması ve yalnızca Milli Ĕ̆itim Bakanlı̆̆ tarafından kullanıldığından yaygın olmaması açısından da BILLSEM'e yerleştirmelerde kullanılması daha güvenilir ve sağliklı değerlendirme sağlamaktadır." (PD13). PD12 kodlu öğretmen ise bu görüşleri şu şekilde özetlemiştir: "BILSEM seçmelerinde WNV Türkiye uyarlamasının kullanılması, bu testin sinırl saynda ve iyi muhafaza edilmesi 2020/2 kişilerin bu teste ulaşımını zorlaştırmıştır. Bu durum daha nesnel bir değerlendirme adına fayda sağlamıştır”. Bunun yanı sıra WNV Testinin işlevsel, kısa süreli 
ve pratik olması ve güncel ve orijinal olması bakımından da önemli olması öğretmen görüşlerine şu şekilde yansımıştır: "WNV testinin yakın zamanda uyarlanmış olması onun daha güncel olmasını yani daha işlevsel olmasını sağlıyor. Ayrıca bu testin WISC-R testine göre daha kısa sürmesi onun işlevselliğini arttırıyor". Başka bir öğretmen ise bu durumu şu şekilde ifade etmektedir: “WNV testinin WISC-R'a nazaran günümüz testlerine yakın olduğunu ve daha kısa sürdüğünü söyleyebilirim. Ayrıca WNV testinin görsel algıyı ölçmesi açısından son derece değerli bir test olduğunu düşünüyorum" (PD15). Bu görüşü destekleyen diğer bir ifadeyi PD5 kodlu öğretmenin düşünlerine şu şekilde yansımıştır: 'Daha kısa sürede daha çok öğrenci inceleme imkânı sunması olumlu tarafi. Geçerlik ve güvenirliği de yüksek olmasına karşın WNV'nin WISC-R'den daha az alanın ölçmesi olumsuz bir durum oluşturuyor". Psikolojik danışmanlar sözel bölümün ölçülmesinin eksik olmasından, sorulara ulaşılmasının zor olmasından ve WNV testinin kullanımının kolay olmasından da bahsetmişlerdir. PD11 kodlu psikolojik danışman "Uygulama sürecinde oldukça ayırt edici ve işlevsel bir test olduğunu düşündüm. Ancak sözel olmayan bir test olması eleştirilebilir." derken PD9 kodlu öğretmen ise "WISC-R testini insanlar bakkalda şeker alır gibi kolayca alabilmekteydi. Bu durum testin ele ayağa düşmesine neden oldu. BILSEM seçmelerine girecek olan çocuklarn WISC-R testini bir gün öncesinde bir psikolojik danışman tarafından uygulanmasın sağlayarak ertesi gün BILLSEM seçmelerine katıldıklarını da çokça duymuştuk. Bu durum kontrolden çıktığından bu test yerine WNV testinin kullanımına geçmenin faydalı olduğunu düşünmekteyim." görüşünü belirtmiştir.

Psikolojik danışmanlardan alınan görüşlere göre, WISC-R zekâ testinde eleştirilere konu olan hususların bu testle giderildiği ancak bu testin WISC-R zekâ testine göre daha az alt alanını ölçmesi ve sözel olmayan bir test olması eleştirilmiştir.

"BİLSEM tanılama sürecinde ilk kez bu yıl kullanılan WNV Testinin, grup tarama tablet testinde başarılı olan öğrencilere uygulanma süreci ile ilgili görüşleriniz nelerdir?" sorusuna psikolojik danışmanların verdikleri cevapların sıklık dağılımları Tablo 3'te verilmiştir.

Tablo 3. Psikolojik danışmanların WNV Testinin Uygulama Sürecine İlişkin Görüşleri

\begin{tabular}{|l|c|c|}
\hline WNV Testinin Uygulama Süreci & f & \% \\
\hline Süreç Sağlıklı işlemekte & 8 & 25,81 \\
Performans, Dikkat ve Algıyı Ölçmede Başarılı & 6 & 19,35 \\
Geçerliği ve güvenirliği yüksek & 5 & 16,13 \\
Uygulama süresi kısa & 4 & 12,90 \\
\hline
\end{tabular}




\begin{tabular}{|l|c|c|}
\hline WNV Testinin Uygulama Süreci & f & $\mathbf{\%}$ \\
\hline Zor ve Yorucu Değil & 4 & 12,90 \\
Akademik Başarı Ön Eleyicisi Olmalı & 2 & 6,45 \\
Sözel ifade olmalı & 1 & 3,23 \\
Testin Örnek Maddeleri Basit & 1 & 3,23 \\
\hline Toplam & 31 & 100 \\
\hline
\end{tabular}

Tablo incelendiğinde BILLSEM tanılama sürecinde ilk kez bu yıl kullanılan WNV testinin, grup tarama tablet testinde başarılı olan öğrencilere uygulanma süreci ile ilgili görüşlerinin başında sürecin sağlıklı işlediği $(\% 25,81)$ ve WNV testinin performans, dikkat ve algıyı ölçmede başarılı olduğu (\%19,35) ifade edilmiştir. (PD8)'e göre “Testin tüm Türkiye'de eş zamanl yapılması ve her test uygulayıcısına göre günlük dört öğrenci düşmesinin güzel bir uygulama olduğunu düşünüyorum. Sürecin kendi ikliminde sağllklı bir şekilde devam ettiği kanaatindeyim". (PD5)'e göre "Öğrencilerin dikkatini çeken bir içeriğ̈in olması öğrencilerin sürece daha aktif olarak katılımını să̆ladı. Çekingen öğrencilerin test sürecinde kendini daha iyi hissetmesini sağlayan bir testti. Öğrencilerin performanslarını rahatlıkla ortaya koymalarını sağlamıştır. WNV de çocuğun performansını, dikkatini ve algısını ölçmede oldukça başarılı bir test olduğunu düşünüyorum”. Başka bir öğretmenin ifadesi ise şu şekildedir: "Sürecin önceki yıllara göre daha sağlıkl olduğu kanaatindeyim. Akademik başarı zekânın salt belirleyicisi olmadığı ama zekânın bir göstergesi olduğu kabul edilirse; grup taraması sonrası WNV yetenek testi uygulanması daha fazla yarar sağlayacağını düşünmek yanlış olmaz." (PD6).

WNV testinin, grup tarama tablet testinde başarılı olan öğrencilere uygulanma sürecinde WNV testinin geçerli ve güvenilir olduğunu $\% 16,13$ ifade etmişlerdir: "Genellikle taramadan geçen çocuklar WNV'de 120 ve üstü almışlardır. Bu anlamda eleyici olduğu söylenebilir. Bu durumda geçerlik ve güvenirliği artırmaktadır."(PD4). Bazı öğretmenler de uygulama süresinin kısa \%12,90 ve zor, yorucu olmadığını ifade etmişlerdir. PD13 kodlu öğretmen bu görüşü şu şekilde desteklemiştir: "WNV testine alınan öğrenciler, uygulamaya kısa sürede adaptasyon sağlamakta ve WNV testi, WISC-R testi kadar uzun ve yorucu olmadığından ilgide azalma ve dikkat seviyesinde düşme gibi durumlar minimize olmaktadır." PD2 kodlu öğretmen ise bu görüşü şu şekilde desteklemiştir: "Uygulama süresi ve test uygulayıcı becerileri açısından oldukça az 2020/2 zorlayıcı bir süreç. Bir süreç bir uygulama yarım saatte de bitebiliyor. Bir gün içinde değerlendirmeye alabileceğiniz öğrenci sayısı da buna bağlı olarak artıyor. Geçerlik ve güvenirlik katsayıları ile ilgili bir problemde yok." 
Akademik başarı ön eleyicisi olmalı, testin örnek maddeleri basit, sözel ifade olmalı gibi ifadelere değinen psikolojik danışman sayısı ise az olmakla birlikte PD1 kodlu öğretmen "Test sözel yeteneğe dayah olmadığından öncelikle yeteneğin bir diğer bağlamda ele alınmast yani belli oranda akademik performanstan sonra uygulanması doğru olacaktır”. PD6 Kodlu öğretmenin yorumu dikkat çekicidir; "Test ortalama 40 dk sürüyor. 2 ve 3. sinıftaki öğrenciler için testin 8 yaş öncesi ve sonrası farklılı̆̆ı belirgin bir zorluk süreci oluşturuyor gibi. 3. sınıf öğrencilerinin ağırlıkla başarısız olduğu dikkatimi çekti. Ayrıca testin resimli tanttım ve örnek maddeleri BILLSEM tanılamalarında üstün adayı öğrencileri için çok basit ve gereksiz kalıyor". Diğer bir öğretmen ise "Öğrenciler WNV testinde bazı kısımları hiç anlamadıklarını ve zorlandıkların belirttiler. Biraz daha sözel ifade olsaydı ve anlaşılır olsaydı daha fazla yararlı olurdu diye düşünüyorum." demiştir.

Psikolojik danışmanlardan alınan görüşlere göre, büyük çoğunluğu WNV testinin uygulanma sürecini olumlu bulmuşlardır. Testte sözel ifadenin eksik oluşu yüzünden öğrencilerin bazı kısımları anlamakta zorlanmaları ise eleştiri konusu olmuştur.

“WISC-R Zekâ Testi ve WNV Testinin üstün zekâyı ayırt etme gücü ile ilgili görüşleriniz nelerdir?” sorusuna psikolojik danışmanların verdikleri cevapların sıklık dağılımları Tablo 4'te verilmiştir.

Tablo 4. Psikolojik danışmanların WISC-R ve WNV Testinin Üstün Zekâyı Ayırt Etme Gücüne İlişkin Görüşleri

\begin{tabular}{|l|c|c|}
\hline WISC-R ve WNV Testinin Üstün Zekâyı Ayırt & f & \% \\
\hline Etme Gücü & 6 & 37,50 \\
WNV oldukça ayırt edici & 5 & 31,25 \\
WISC-R daha ayırt edici ancak güncellenmeli & 3 & 18,75 \\
WNV dil yönüyle eksik & 1 & 6,25 \\
Her iki testte başarılı & 1 & 6,25 \\
İlerleyen yıllarda değerlendirilmeli & 16 & 100 \\
\hline Toplam & & \\
\hline
\end{tabular}

Tablo incelendiğinde WISC-R zekâ testinin \%31,25 WNV yetenek testinin \%37,50 ile üstün zekâyı ayırt etme gücü ile ilgili görüşlerin yüzdelik dilimlerine bakıldığında çok da birbirinden uzak olmadığı görülmektedir. Fakat \%18,75 ile öğretmenler WNV testinin dil yönüyle eksik olduğunu da belirtmişlerdir. WISC-R daha ayırt edici ancak güncellenmeli görüşüu ikinci sırada yer almaktadır. Öğretmenlerin bu konudaki düşünceleri: 
"WISC-R ölçeğinde alt test sayısının fazla olması ve sözel puanı bulmaya yönelik alt test sayısının fazlalığı zekâyla ilgili daha objektif bilgi verdiği düşünülmektedir. Ancak uzun yıllardır uyarlama yapılmadığı için günümüze uygunluğu her geçen yıl azalmaktadır." (PD14). "WISC-R zekâ testi performansı ölçmenin yanı sıra sözel bilgi beceri ve muhakeme gücünü de ölçmesi bakımından daha kapsamlı ancak güncellenmeye gereksinimi olan bir testtir”. (PD13) kodlu öğretmen görüşlerini şu şekilde ifade etmiştir; 'WNV yetenek testinin grup tarama tablet testinde başarılı olan öğrencilere yönelik öğrencinin parlak zekâya mı yoksa üstün zekâya mı sahip olduğunu ayırt edebilecek düzeyde olduğu kanısındayım". PD4 kodlu öğretmen "WNV testinin ayağa düşmemesi ve normlarının yeni toplanması, kültürümüze uyarlanması açısından güçlü buluyorum. Yine de üstün zekâyı ayırt ederken zekânın çok boyutlu düşünülüp sözeli de ölçmesi daha kapsamlı olacaktır." şeklinde ifade etmiştir. Bir öğretmen her iki testi de başarılı bulurken diğer bir öğretmen ise bu değerlendirmeyi ilerleyen yıllarda WNV sonuçları alındıkça yapmanın daha doğru olacağı görüşünü paylaşmıştır. Psikolojik danışmanlardan alınan görüşlere göre, WNV yetenek testi üstün zekâyı ayırt etmede oldukça iyi bulunmakla birlikte sözel yönüyle eksik bulunmuştur. WISC-R testinin ise daha ayırt edici olduğu fakat güncellenmesi gerektiği belirtilmiştir.

\section{Bilim Sanat Merkezlerinde Görev Yapan Öğretmenlerden Elde Edilen Bulgular}

“Size göre BİLSEM'e kabul yaşı kaç olmalıdır?” sorusuna BİLSEM öğretmenlerinin verdikleri cevapların sıklık dağılımları Tablo 5'te verilmiştir.

Tablo 5. BiLSEM öğretmenlerinin Öğrencilerin BILLSEM’e Kabul Yaşına İlişkin Görüşleri

\begin{tabular}{|l|c|c|}
\hline BİLSEM Kabul Yaşı & f & \% \\
\hline Okul Öncesi çağda alınmalı & 11 & 61,11 \\
\hline 6 Yaş & 3 & 16,67 \\
\hline 7 Yaş & 3 & 16,67 \\
\hline 11 Yaş & 1 & 5,56 \\
\hline Toplam & 18 & 100 \\
\hline
\end{tabular}

Çocuk ve Medeniyet 2020/2
Tablo incelendiğinde 18 BİLSEM öğretmenlerinin \%61,11 ile büyük çoğunluğunun öğrencilerin BİLSEM kabul yaşının okul öncesi çağda olması 
gerektiğini söyledikleri görülmektedir. Öğretmenlerin ifadelerine bakacak olursak B2 kodlu öğretmen "Alt yapı uygun olduğunda okul öncesi dönemden başlanmalıdır" şeklinde ifade etmiştir. Diğer bir öğretmenin ifadeleri ise şu şekildedir: "Mümkünse en erken tanılama okul öncesinde yapılmalıdır. Fakat ülke gerçekleri göz önünde bulundurulursa 2. Sinfflardan itibaren öğrencilerin alınması uygun görünüyor". Bir öğretmen ise BİLSEM kabul yaşının 11 olması gerektiğini ifade etmiştir. BİLSEM öğretmenlerinden alınan görüşlere göre, BİLSEM'lerde eğitim erken yaşlarda başlamalıdır. Hatta büyük çoğunluğa göre okul öncesi yaşlarda başlamalıdır.

“Daha önceki yıllarda uygulanan TKT ile tanılanarak gelen öğrencilerle son üç yılda uygulanan grup tarama testi ile gelen öğrenciler arasında zihinsel performans açısından farklılıklar nelerdir?" sorusuna BILLSEM öğretmenlerinin verdikleri cevapların sıklık dağılımları Tablo 6'da verilmiştir.

Tablo 6. BİLSEM öğretmenlerinin Zihinsel Performans Açısından TKT İle GTTT Farkına İlişkin Görüşleri

\begin{tabular}{|l|r|c|}
\hline Zihinsel Performans Olarak TKT İle Grup Tarama Farkı & f & \% \\
\hline Fark yok & 12 & 66,67 \\
TKT daha başarılı & 5 & 27,78 \\
Grup Tarama testleri daha başarılı & 1 & 5,56 \\
\hline Toplam & 18 & 100 \\
\hline
\end{tabular}

Tablo incelendiğinde BİLSEM öğretmenlerinin \%66,67'si fark olmadığına dikkat çekmişlerdir. Öğretmen görüşleri ele alındığında B6 kodlu öğretmen “TKT ve GTTT'inde öğrenci boyutunda sıkıntılar yaşanıyordu. Ama zihinsel performans olarak bir farklılık yok.” şeklinde ifade etmiştir. TKT'nin daha başarılı olduğunu ifade eden öğretmenlerden B3 kodlu öğretmenin görüşleri de şu şekildedir: “TKT ile gelen öğrencilerin daha verimli olduğunu düşünüyorum. TKT veya GTT'de sorular bütün alanların kapsayacak şekilde hazırlanmalı." Bir öğretmen ise grup tarama testlerinin daha başarılı olduğunu ifade etmiştir. BİLSEM öğretmenlerinin büyük çoğunluğu, öğrenciler arasındaki zihinsel performans olarak önceki yıllarda TKT ile gelenlerle, son yıllarda GTTT ile gelenler arasında fark görmemektedirler. "Daha önceki yıllarda uygulanan TKT ile tanılanarak gelen öğrencilerle son üç yılda uygulanan grup tarama testi ile gelen öğrenciler arasında BİLSEM etkinliklerine uyumları açısından farklılıklar nelerdir?" sorusuna 
BİLSEM öğretmenlerinin verdikleri cevapların sıklık dağılımları Tablo 7'de verilmiştir.

Tablo 7. BİLSEM öğretmenlerinin, Öğrencilerin BILLSEM etkinliklerine uyumları Açısından TKT İle GTT Farkına İlişkin Görüşleri

\begin{tabular}{|l|r|c|}
\hline TKT ile Grup Tarama Uyum Süreci & f & $\mathbf{\%}$ \\
\hline Fark yok & 14 & 77,78 \\
Grup tarama ile gelenler daha uyumlu & 2 & 11,11 \\
TKT ile gelenler daha uyumlu & 2 & 11,11 \\
\hline Toplam & 18 & 100 \\
\hline
\end{tabular}

Tablo incelendiğinde, BİLSEM öğretmenlerinin büyük çoğunluğu (\%78) fark olmadığını dile getirmiştir. B5 kodlu öğretmen "Hemen hemen aynı, ikisinde de fark yok ve uyum açısından bir farklılık görmüyorum." demiştir. Bazı öğretmenler grup tarama ile gelenlerin daha uyumlu olduğundan bahsetmişlerdir. "Grup tarama ile gelenlerin daha rahat olduğunu düşünüyorum. Eskiler daha uyumlu." (B9). Dikkat çeken başka bir nokta ise B8 kodlu öğretmenin ifadelerine şu şekilde yansımıştır: "Uyum süreci açısından fark var. Fakat bu durumu testlere bağlamamak gerekir. Nesil farkı açısından (daha nazl yetiştiren, sosyo-demografik durum vb.) Uyum sürecinde farklılık bulunmamaktadır”. BİLSEM öğretmenlerinin büyük çoğunluğu, öğrenciler arasındaki öğrencilerin BİLSEM etkinliklerine uyumları açısından önceki yıllarda TKT ile gelenlerle, son yıllarda GTTT ile gelenler arasında fark görmemektedirler.

“Tanılama süreciyle BİLSEM’lere kabul edilen öğrencilerin doğru seçilip-seçilmediğiyle ilgili görüşleriniz nelerdir?" sorusuna BİLSEM öğretmenlerinin verdikleri cevapların sıklık dağılımları Tablo 8'de verilmiştir.

Tablo 8 incelendiğinde tanılama sürecine ilişkin BİLSEM'lere kabul edilen öğrencilerin doğru seçilip seçilmediğiyle ilgili görüşmeler sonucunda sadece \%16,67'si kullanılan yöntemin uygun olduğunu belirtmişlerdir. Tablo incelendiğinde büyük çoğunluğun, 18 öğretmenin 15'inin \%84,33 ile seçim sürecine dair eleştirel düşüncelere sahip olduğu gözlenmiştir. Bu düşüncelerin başında \%44,44 ile birinci grup elemeden kaynaklı her çocuğa ulaşılamaması birinci sırada yer almaktadır. 
Tablo 8. BILLSEM öğretmenlerinin BİLSEM Öğrencilerinin Seçilme Yöntemlerine İlişkin Görüşleri

\begin{tabular}{|l|c|c|}
\hline BİLSEM Öğrencilerinin Seçilme Yöntemleri & f & \% \\
\hline $\begin{array}{l}\text { Birinci grup elemeden kaynaklı her çocuğa ulaşılamama } \\
\text { durumu var. }\end{array}$ & 8 & 44,44 \\
Alternatif yöntemler kullanılmalı & 4 & 22,22 \\
Kullanılan yöntem uygun & 3 & 16,67 \\
Kullanılan yöntem uygun değil & 2 & 11,11 \\
Deha seviyesinde öğrencilerin tespitinde sıkıntı var & 1 & 5,56 \\
\hline Toplam & 18 & 100 \\
\hline
\end{tabular}

BİLSEM Öğretmenlerin görüşleri şu şekildedir: "Yüzde yüz başarılı seçildiğini düşünmüyorum. Alternatifler üretilmeli ve ülkemiz şartları dikkate alınmalıdır. Kısaca buraya nasıl seçilmiş diye düşündüğüm öğrencilerim var.” (B3). Başka bir öğretmen “\%80 öğrencilerin doğru geldiğini düşünüyorum. Deha seviyesinde öğrencilerin tespitinde sıkıntı var. Deha seviyesindeki öğrenciler çok az geliyor." olduğunu belirtmiştir (B5). BİLSEM Öğretmenleri alternatif yöntemler kullanılması gerektiğini belirtmiştir. B6 kodlu öğretmen bu durumu şu şekilde ifade etmiştir: "Tanılama süreci birkaç aşamalı olursa çocuğun (sınav kaygısı vb.) olumsuz durumlardan kaynaklı tanılamama durumunun ortadan kalkacağını ve çocukların en az iki kez bu süreçten geçirilebileceğini düşünüyorum.”. Bazı öğretmenler ise ilçe ve köydeki öğrencilere tam manasıyla ulaşılamadığını ifade etmişlerdir. Bu durum B7 kodlu BİLSEM öğretmeninin ifadelerine şu şekilde yansımıştır: "Şu anki süreçte doğru seçilmediğini düşünüyorum. Sınıf öğretmenlerinin aday göstermedeki bilgisizliklerinden kaynaklanan ilçe köy vb. genele ulaşılamadığın düşünüyorum. Bu süreç daha fazla detayl ve belli rutinlerle tekrarlanmal. Çocukların soysa ekonomik durumlarının da bunda etkili olduğu kanaatindeyim". BİLSEM öğretmenlerinden alınan görüşlere göre, öğretmenlerin büyük çoğunluğu BİLSEM öğrencilerinin seçilme yöntemlerinde sıkıntı olduğunu düşünmektedirler.

“Özel yeteneklileri tanılama sürecinde kullanılan zekâ testleriyle ilgili görüşleriniz nelerdir?” sorusuna BİLSEM öğretmenlerinin verdikleri cevapların sıklık dağılımları Tablo 9'da verilmiştir. 
Tablo 9. BİLSEM Öğretmenlerinin Tanılama Sürecinde Zekâ Testlerinin Özelliklerine İlişkin Görüşleri

\begin{tabular}{|l|c|c|}
\hline Testlerinin Özellikleri & f & \% \\
\hline Yeni test güncel ve uygulaması olumlu & 10 & 32,26 \\
Yeni testin dilden arındırılmış olması düşündürücü & 7 & 22,58 \\
WISC-R zekâ testi ayırt ediciliği yüksek ve uygun bir test & 7 & 22,58 \\
Testlerin içeriği hakkında bilgili değilim & 4 & 12,90 \\
Milli testler geliştirilmeli & 3 & 9,68 \\
\hline Toplam & 31 & 100 \\
\hline
\end{tabular}

Tablo incelendiğinde öğretmenlerin testlerine yönelik görüşlerinin başında Yeni testlerin güncel ve uygulamasının olumlu olduğu $(\% 32,26)$ gelmektedir. "Yeni testin uygulamasın olumlu buluyorum ama bunun da süre içinde görülüp sonuçlarının zamanla anlaşılacağını düşünüyorum." (B8). İkinci olarak BILLSEM öğretmenlerinin özel yetenekli öğrencileri tanılama sürecinde kullanılan yeni testin dilden arındırılmış olmasının düşündürücü bir etken olduğu \%22,58 ile gelmektedir. B1 kodlu BİLSEM öğretmenleri görüşlerini şu şekilde belirtmişlerdir. "Yeni test hakkında çok bilgimiz olmamakla birlikte dilden arındırılmış olması düşündürücü bir etki. Zamanla sonuçlar çıktıkça daha iyi anlaşılacaktır”. Üçüncü olarak BİLSEM öğretmenlerinin özel yetenekli öğrencileri tanılama sürecinde daha önce kullanılan WISC-R testinin ayırt ediciliği yüksek ve uygun bir test olduğu $(\% 22,58)$ gelmektedir. Bu konuda B1 kodlu BILLSEM öğretmenleri görüşlerini şu şekilde belirtmişlerdir. "WISC-R zekâ testi ayırt ediciliği gayet yüksek bir test olup BILLSEM seçmeleri için uygun bir test idi”. Dördüncü olarak BİLSEM öğretmenlerinin özel yetenekli öğrencileri tanılama sürecinde kullanılan testlerinin içeriği hakkında bilgili olmaması $(\% 12,90)$ gelmektedir. B1 Kodlu öğretmenin "testlerinin içeriği ile ilgili bilgi sahibi değilim." ve başka bir öğretmen ise "Çok fazla bilgim yok." şeklinde belirttiği ifadelerinde de anlaşıldığı gibi içerik hakkında çok bilgi sahibi olmadıkları ayrıca yapılan görüşmede BİLSEM Psikolojik danışmanlar kendilerine yeni testle ilgili bir eğitim verilmediğini belirtmişlerdir. BİLSEM öğretmenlerinin üzerinde önemle durduğu bir başka önemli nokta da \%9,68 ile milli testlerinin geliştirilmesidir. B11 kodlu öğretmenin ifadesi ise şu şekildedir: "testleri milli olmalıdır. Dünya yeni testleri kullanırken biz hala 20 sene öncesindeki testleri kullanıyoruz". BİLSEM öğretmenleri yeni test hakkında çok fazla bilgi sahibi olmamakla birlikte sözel yönüyle eksik oluşuna biraz 2020/2 temkinli yaklaşmışlardır. Bununla birlikte güncel bir testin uygulanmasını olumlu bulmuşlardır. Bu kurumlarda çalışan psikolojik danışmanların 
görüşlerine göre ise WISC-R testi üstün zekâyı ayırt ediciliği yüksek bir testtir.

“Varsa görüş ve önerileriniz nelerdir?” sorusuna BİLSEM öğretmenlerinin verdikleri cevapların sıklık dağılımları Tablo 10'da verilmiştir.

Tablo 10. BILLSEM öğretmenlerinin Görüş ve Önerileri

\begin{tabular}{|l|c|c|}
\hline Görüş ve öneriler & f & \% \\
\hline Tanılama süreci ile ilgili yorumlar & 9 & 50 \\
Yok & 6 & 33,33 \\
BİLSEM işleyişi ile ilgili yorumlar & 3 & 16,67 \\
\hline Toplam & 18 & 100 \\
\hline
\end{tabular}

Tablo incelendiğinde öğretmenlerin \%33,33'ünün yorum yapmadığ gözlenmiştir. Öğretmenlerin \%50'si tanılama sürecine yönelik öneriler belirtmişlerdir. Bunlardan B3 kodlu öğretmen, "Sadece T.K.T, GTT veya Wischler, WNV gibi testleri ile tanılama yapılması bence çok mantıksız. Portfolyo sistemi mutlaka olmalı. Çocuğun küçük yaşlardan itibaren izlenerek yaptı̆̆ı bütün çalışmaların olduğu dosyalar aile görüşleri, veli ve sınıf öğretmenlerinin görüşleri, katıldiğı etkinlikleri kapsayan dosya oluşturulmal, bunlardan sonra TKT ve testleri uygulanmalıdır”. B1 kodlu öğretmenler ise “Tek bir ZEKÂ testiyle değil tanılamanın çok aşamalı ve gelişim dosyaları $v b$. birçok kaynaktan faydalanarak yapılması daha doğru olur. Doğru olanın ilk eleme sinavina giren bütün çocukların testinden geçmesi gerektiği fakat ülke şartlarında bunun çok ütopik olduğu gerçeğidir” şeklinde açıklamışlardır. Diğer bir öğretmen ise "Gezici kurul oluşturulabilir. Öğrencilerin taranması noktasında daha çok öğrenciye ulaşılsın. Değerlendirmeye katılamayan ve spor, müzik vb. yetenekleri olan öğrencilere de şans verilmesi gerektiğini düşünüyorum." açıklamalarında bulunmuştur. BİLSEM işleyişi ile ilgili yapılan yorumlar incelendiğinde ise B10 kodlu öğretmen "BILLSEM'ler çok iyi işliyor”. B8 kodlu öğretmen “BİLSEM'lerin bağımsız okul olması gerektiğini, bu öğrencilere genel sınavlarda teşvik puanı $v b$. verilmesi gerektiğini çünkü ailelerin çocuk tanılanana kadar iyi baktığ fakat ilerleyen zamanlarda sistem gereği dershane $v b$. durumların ön plana çıkarak BILLSEM'lerin ikinci plana atıldı̆̆ını"; diğer bir öğretmen ise "Bütün okullarda BILLSEM imkânlarının olması gerektiğini, ailelerin kurumu dershane gibi düşündükleri için ailelere de BILLSEM eğitimi hakkında daha fazla bilgi verilmesi 2020/2 gerektiğini" belirtmiştir. BILLSEM öğretmenlerinden alınan görüşlere göre, tanılama sürecinde daha çok öğrenciye ulaşılmalı ve alternatif yöntemler kullanılmalıdır. 


\section{Sonuç, Tartışma ve Öneriler}

Araştırma bulgularına göre WISC-R testinin işlevsel, geçerli, güvenilir ve kapsamlı olmakla birlikte uygulamasının uzun zaman aldığı, zorlayıcı olduğu, ulaşılabilirliğinin arttığı bu yüzden güvenirliliğini yitirdiği ve yenilenmeye ihtiyacı olduğu sonucuna ulaşılmıştır. WISC testinin 1974 yılında revize edilmesi ile WISC-R adını alan sürümü 1991'de WISCIII önemli değiş̧iklikler ile yayınlanmıştır. Bu sürümünde önceki bileşik puanlar değiştirilmiş ve Sözel Kavrama Endeksi, Algısal Akıl Yürütme Endeksi, Dikkati Koruma Endeksi ve İşlem Hızı Endeksi geliştirilmiştir (Öpengin, 2019). 2003 yılında WISC-IV sürümü oluşturulmuştur. WISC testinin en güncel versiyonu ise bir önceki versiyonun güncelleştirilmesi olan WISC-V olup 2014 yılında yayınlanmıştır. Güncel WISC-V testinde alt ölçek sayısı arttırılmıştır. Toplamda 21 alt ölçeği olan bu versiyonda en az 7 alt ölçek ile Tüm Test Zekâ Puanı (FSIQ) hesaplanmaktadır. Ayrıca Sözel Kavrama Endeksi (VCI), Görsel-Uzamsal Endeks (VSI), Akıcı Muhakeme Endeksi (FRI), Çalışan Bellek Endeksi (WMI) ve İşlem Hızı Endeksi (PSI) puanlarının yanı sıra alt testlerin çeşitli şekillerde bir araya getirilmesi ile 16 farklı bileşik puan hesaplanabilmektedir (Kaufman, Raiford ve Coalson, 2015). Görüldügü gibi dünya genelinde yeni sürümleri oluşturulan WISC-R ülkemizde halen 1974'deki sürümü ile kullanılmaktadır. Ayrıca dünya genelinde son sürümü ile daha kapsamlı olan WISC-V sürümünün kullanılıyor olması öğretmenlerin kapsamlı bir test kullanılması görüşünü destekler niteliktedir.

Psikolojik danışmanların BİLSEM tanılama sürecinde WNV Testinin üstün zekâyı ayırt etmede oldukça iyi olduğunu ve uygulanmasının sağlıklı bir şekilde yürütüldüğünü ancak sözel bölümünün olmayışını bir eksiklik olarak görmektedirler. Bununla birlikte WISC-R zekâ testinde eleştirilere konu olan hususların bu testle giderildiğini düşündükleri görülmektedir. Öğretmenlerin bu görüşlerinde haklı oldukları görülmektedir. Zira güncel WISC-V sürümünün sözel alt boyutu da mevcuttur(Kaufman, Raiford ve Coalson, 2015).

Bu araştırmada özetle zekâ testi uygulayan psikolojik danışmanların tanılama sürecinde yapılan grup tarama ve zekâ testleriyle ilgili görüşleri BİLSEM'lerde görev yapan öğretmen görüşleriyle örtüşmekte olup eski testin (WISC-R) geçerli ve daha kapsamlı olduğu fakat çok fazla kişiye ulaştığı için güvenirliliğini yitirdiği bu yüzden yeni bir teste ihtiyaç duyulduğu yeni testin (WNV) ise sözel ifade yönüyle eksik olduğu sonuçlarına ulaşılmıştır. Rehber öğretmelerle yapılan görüşmelerde WNV $2020 / 2$ testinin, WISC-R Zekâ Testine göre daha az alt alanını ölçtüğü ve uygulanışı sırasında sözel ifade kullanılmadığı için öğrencilerin bazı kısımları 
anlamakta zorlandıklarını belirtmişlerdir. Bu noktada WNV testinin eksik bulunan özellikleri için sağaltım çalışmaları yapılarak eleştirilen hususların düzeltilmesi yoluna gidilebilir.

BİLSEM'de görev yapan öğretmenlerin büyük çoğunluğuna göre BİLSEM kabul yaşı okul öncesi dönemde olmalıdır. Aslında bu durum ülkemizdeki özel yetenekliler ile ilgili yapılan Üstün Yetenekliler/Zekalılar Çalıştayı (BILLSEM Modeli) Raporu (2009), Üstün Yeteneklilerin Eğitimi Ortak Akıl Platformu 20-22 Aralık (2010), 2012-2013 Eğitim Öğretim Yılında Düzenlenen Özel Yetenekli Bireyler Çalıştay Raporları ve Özel Yetenekli Bireyler Strateji ve Uygulama 2013 - 2017 Planında da belirtilmiştir. Ancak ülkemizde erken çocukluk döneminde tanılama ve özel yeteneklilerin eğitimi ile ilgili henüz bir yol alınamamıştır. Ülkemizde bir an önce erken çocukluk dönemindeki özel yetenekli öğrencilerin tanılanması ve eğitimleri için gerekli tedbirler alınmalıdır.

BIILSEM öğretmenlerinin görüşlerine göre TKT ile seçilen öğrencilerle, son yıllarda GTTT ile seçilenler arasında zihinsel performans açısından fark görülmemektedir. Aslında grup testleri bireysel zeka testine geçiş aşamasında etkili olmaktadır. Ve son olarak öğrenci grup tanılama testlerine göre değil bireysel zeka testine göre seçilmektedir. Bu nedenle TKT grup tarama testi ile seçilen öğrenciler ile GTTT ile seçilen öğrencilerin zihinsel performansları arasına fark görülmemesi doğal kabul edilebilir.

BİLSEM tanılama sürecinde öğrencilerin seçilme yöntemlerinde sıkıntı olduğu görülmektedir. Öğretmenler, birinci grup elemeden kaynaklı her çocuğa ulaşılamama durumunun söz konusu olduğunu ve kullanılan yöntemlerin uygun olmadığını, bunun yerine alternatif yöntemler kullanılması gerektiğini belirtmişlerdir. Bu sonuçlar, Mantzicopoulos (2000)'deki çalışma sonuçlarıyla paralellik göstermektedir. Mantzicopoulos bir yıl boyunca okul öncesi eğitimi alan 6 yaş grubu, 13'ü özel yetenekli olan 134 çocukla ve öğretmenleriyle çalışarak akademik beceri değerlendirme ölçeğinin özel yetenekliliği ayırt edip etmediğini incelemiştir. Araştırmada öğretmenlere akademik beceri değerlendirme ölçeği verilerek sınıflarındaki öğrencileri değerlendirmeleri istenmiştir. Araştırma sonucunda; özel yetenekli öğrencilerin özelliklerine ilişkin özel eğitim almayan öğretmenlerin değerlendirmelerinin güvenilir olmadığı sonucuna varılmıştır. Öğretmenlerin alternatif tanılama yöntemleri kullanılması gerektiği konusunda getirdikleri önerileri ise Brown, Renzulli, Gubbins, Zhang ve Chen (2005) ve Minton ve Pratt'daki (2006) araştırma sonuçlarıyla paralellik göstermektedir. Brown ve meslektaşları 2020/2 akademisyen, eğitim liderleri, özel yeteneklilik alan uzmanları, yöneticiler ve sınıf öğretmenlerinin özel yetenekli öğrencileri belirlerken kullandıkları 
varsayımları tespit etmek üzere bir araştırma yapmışlardır. Araştırmaya dâhil edilen denekler üstün yetenek konusunda ulusal konferans veya atölye çalışmalarına en az iki defa katılmış olanlar arasından seçilmiştir. Araştırma kapsamında 6000 deneğe e-mail yoluyla 20 maddeden oluşan bir araştırma formu gönderilmiştir. Araştırma sonucunda, değerlendirme sisteminde esnek olunması gerektiği, sadece zekâ testleri veya başarı testi ile sınırlı bir tanılama sisteminin uygun bir değerlendirme sistemi olmadığı ve değerlendirmede çoklu kriter kullanılması gerektiği belirlenmiştir.

Minton ve Pratt ise WISC- III ile tanılanmış ve özel yetenekli öğrenciler için yürütülen bir eğitim programına devam eden özel yetenekli36 öğrenciye Stanford- Binet- V Zekâ Testini de uygulamışlardır. Araştırmacılar, WISC- III Zekâ Testinde ilk altıya giren özel yetenekli öğrencilerden (zekâ aralıkları 149-154 ZEKÂ puanı) yalnızca ikisinin Stanford- Binet- V Zekâ Testinde ilk altıya girebildiklerini saptamışlardır. Aynı araştırmanın ortaya koyduğu daha çarpıcı bir bulgu ise, WISC- III' de özel yetenekli bulunan diğer dört öğrencinin Stanford- Binet- V Zekâ Testinde özel yetenekli bile tanılanmamalarıdır. Araştırma bulguları, özel yetenekli öğrencileri tanılama uygulamalarında kullanılan tanılama aracının türünün ne denli önemli sonuçlar doğurabileceğini açıkça ortaya koymaktadır. Bu nedenle özel yetenekli öğrencileri tanılama sürecinde öğrenciler hakkında birden fazla kaynaktan bilgi toplanması son derece önemlidir.
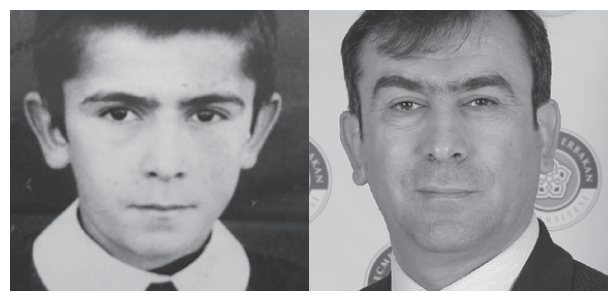

Ahmet Kurnaz

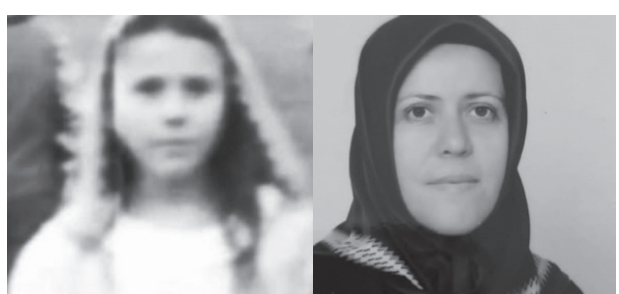

Semra [Gökdemir] Ekici

\section{Kaynakça}

Akarsu, F. (2004). Üstün yetenekliler. R. Șirin, A. Kulaksızoḡlu ve A.E. Bilgili (Ed.), Üstün Yetenekli Cocuklar: Seçilmiș Makaleler Kitabı (s. 211-218) içinde. İstanbul: Çocuk Vakfı Yayınları, 63. 
Ataman, A., Daḡlıoğlu, E. ve Șahin, F. (2014). Üstün zekâlılar ve özel yetenekliler konusunda bilinmesi gerekenler. Ankara: Vize Yayınları.

Ayas, M. B. (2018). Üstün yeteneklileri tanılamaya giriș. Uḡur Sak (Ed.), Üstün yeteneklilerin tanılanması İkinci Baskı içinde, (s.1-14). Ankara: Vize Yayıncııı.

Brown, S.W., Renzulli, J. S., Gubbins, E. J., Zhang, W. ve Chen, C. (2005). Assumptions underlying the identification of gifted and talented students. Gifted Child Quarterly, 49 (1), 68-79.

Callahan, C. M. (2005). Identifying gifted from underrepresented populations. Theory into Practice, 44 (2), 98-104.

Clark, B. (1997). Growing up gifted (Beșinci baskı). New Jersey: Prentice-Hall, Inc.

Davaslıgil, Ü. (2016). Üstün zekalı ve yetenekliler için farkılıștııılmıs matematik programının matematik tutumuna etkisi. Üstün Yetenekliler Eḡitimi ve Araștırmaları Dergisi (UYAD), 3 (2).

Davaslıgil, Ü. (2004). Üstün çocuklar. R. Șirin, A. Kulaksızoḡlu ve A.E. Bilgili (Ed.), Üstün Yetenekli Cocuklar: Seçilmiș Makaleler Kitabı (s. 211-218) içinde. İstanbul: Çocuk Vakfı Yayınları, 63.

Dönmez, B. N. (2014). Üstün; akıl, deha, yetenek, dahiler-savantlar gelișimleri ve eḡitimleri. Ankara: Vize Yayıncılık.

Eker, A., Kurnaz, A. ve Sarı, H. (2017). Üstün yetenekli öğrencileri tanılama süreci. U. Sak (Ed.), Üstün yeteneklilerin tanılanması. Ankara: Vize Yayıncılık.

Eker, A. ve Sarı, H. (2016, Temmuz). A comparison of identification processes between second and fourth grades students enrolled in Turkish science and art centers: From the experts' perceptions. 22. WCGTC Dünya Üstün Yeteneklilerin Eḡitiminde Yeni Perspektifler Kongresi, Avustralya.

Ersevim, İ. (Ed.). (2001). Özel yetenekli çocukların eḡitimi ulusun en büyük kaynaklarından birinin harcanması nasıl önlenir. İstanbul: Özgür Yayınları.

Heller, K. A. (2004). Identification of gifted and talented students. Psychology Science, 46 (3), 302323.

Kaufman, A. S., Raiford, S. E., \& Coalson, D. L. (2015). Intelligent testing with the WISC-V. John Wiley $\&$ Sons.

Kurnaz, A. (2014). Yirminci yılında bilim ve sanat merkezlerinin raporlar ve yönetici görüșlerine dayalı olarak deḡerlendirilmesi. Özel yetenekliler Ēgitimi Araștırmaları Dergisi, 2 (1), 1-22.

Levent, F. (2011). Özel yetenekli çocukların hakları el kitabı anne baba ve öğretmenler için. İstanbul: Cocuk Vakfı Yayınları.

Miles, M. B., \& Huberman, A. M. (1994). Qualitative data analysis: An expanded sourcebook. sage.

Millî Ēgitim Bakanlığı (MEB). (2007). Bilim ve Sanat Merkezleri yönergesi. 16.12.2016 tarihinde http:// www.orgm.meb.gov.tr/ adresinden ulașılmıștır.

Millî Eğitim Bakanlığı (MEB). (2010). Millî Ēgitim Bakanlığı iç denetim birimi bașkanlığı, Bilim ve Sanat Merkezleri süreci (özel yetenekli bireylerin eḡitimi) iç denetim raporu. 16.12.2016 tarihinde http://icden.meb.gov.tr/ adresinden ulașımıștır.

Millî Eḡitim Bakanlığı (MEB). (2016). Bilim ve Sanat Merkezleri okul/kurum sıralı listesi. 15.10.2016 tarihinde http://www.orgm.meb.gov.tr/ adresinden ulașılmıștır.

Minton, B. A. ve Pratt, S. (2006). Gifted and highly gifted students: How do they score on the SB5?. Roeper Review, 28 (4), 232-236.

National Association for Gifted Children (NAGC). (2013). Pre-K- Grade 12 program standards. 17.06.2016 tarihinde https://www.nagc.org/resources-publications/ resources/nationalstandards-gifted-and-talented-education/pre-k-grade-12-0 adresinden ulașılmıștır.

Öpengin, E., (2018). Zeka Testleri. Uḡur Sak (Ed.), Üstün yeteneklilerin tanılanması İkinci Baskı içinde, (s.33-54).. Ankara: Vize Yayıncılık.

398

Çocuk ve Medeniyet 2020/2
Patton, M. Q. (2002). Two decades of developments in qualitative inquiry: A personal, experiential perspective. Qualitative social work, 1(3), 261-283.

Sak, U. (2014). Üstün zekâlılar özellikleri tanılanmaları eḡitimleri (Dördüncü baskı). Ankara: Vize Yayınları.

Ahmet Kurnaz, Semra (Gökdemir) Ekici 
Sak, U. (2011). Üstün yetenekliler eḡitim programları modeli (ÜYEP) ve sosyal geçerliḡi. Ēgitim ve Bilim, 36 (161), 213-229.

Sıcak, A. (2014). Özel yetenekli öğrencilerin aday gösterme sürecinde öḡretmen gözlem puanlarının TKT 7-11 ve WISC-R puanlarını yordayıcılık gücünün incelenmesi. Üstün Zekâlılar Eğitimi ve Yaratıcılık Dergisi, 1 (1) 7-12.

Sternberg, R. J., Jarvin, L. ve Grigorenko, E. L. (2011). Explorations in giftedness. New York, NY: Cambridge University Press.

Șimșek, H. ve Yıldıım, A. (2013). Sosyal bilimlerde nitel araștırma yöntemleri (Genișletilmiș dokuzuncu baskı). Ankara: Seçkin Yayıncılık.

Tomlinson, C. A., Kaplan, S. N., Renzulli, J. S., Purcell, J., Leppien, J. ve Burns, D. (2002). The parallel curriculum: A design to develop high potential and challenge high-ability learners. Thusand Oaks, CA: Corwin Press.

Türkiye Bilimsel ve Teknolojik Araștırma Kurumu (TÜBiTAK). (2010). Özel yeteneklilerin eḡitimi ortak akıl platformu raporu. 18.12.2014 tarihindehttp://orgm.meb.gov.tr/meb_iys_ dosyalar/2013_08/27032244_20_22_aralk_uyoap.pdf adresinden ulașılmıștır.

Türkiye Büyük Millet Meclisi (TBMM). (2012). Özel yetenekli çocukların keșfi, eḡitimleriyle ilgili sorunların tespiti ve ülkemizin gelișimine katkı sağlayacak etkin istihdamlarının saḡlanması amacıyla kurulan meclis araștırma komisyonu raporu. Ankara. 